\title{
THE DUTIES OF THE CORPORATE DEBTOR TO ITS CREDITORS
}

\author{
Robert Charles Clark*
}

Fraudulent conveyance law, equitable subordination doctrine, dividend restraint statutes, and piercing the corporate veil traditionally have been viewed as separate legal theories. Starting with an analysis of the ideals behind fraudulent conveyance law, Professor Clark develops the interrelations between these doctrines and explains their existence as distinct bodies of law.

\section{INTRODUCTION}

7 HE initial thesis of this article is that the law of fraudulent 1 conveyances ${ }^{1}$ contains a few simple but potent moral principles governing the conduct of debtors toward their creditors. Moreover, when these normative ideals are properly distilled and examined, a number of less venerable doctrines concerning corporate debtors can be shown to be functional substitutes for or technically necessary complements to the law of fraudulent conveyances. In particular, the doctrines of equitable subordination and piercing the corporate veil may be seen as applications of the same notions of securing the moral obligations of debtors to creditors which are at work in fraudulent conveyance law.

The near absence of sustained discussion in cases or in the writings of commentators of the relationships among these branches of the law is odd, in view of the importance that these doctrines have to attorneys. ${ }^{2}$ My explanation is that the lack of

* Associate Professor of Law, Yale Law School. A.B. Maryknoll Seminary (Ill.), I966; Ph.D. Columbia, I97I; J.D. Harvard, 1972.

${ }^{1}$ A succinct and general expression of fraudulent conveyance law appears in the INSTITUTES 4.6.6. A more recent expression was given by the statute of $\mathrm{I}_{3}$ Eliz., ch. 5 ( 1571 ). Modern statements include the Uniform Fraudulent Conveyance Act [hereinafter UFCA], which has been adopted by about half of the states, and the Bankruptcy Act's own fraudulent conveyance statute, \& 67d, ir U.S.C. \& ro7(d) ( 1970 ). Important commentary and discussion of case law is provided by V. Country man, Cases and Materials on Debtor and Creditor i27-79 (2d ed. 1974) (notes) ; 2 G. Glenn, Fraudulent Conveyances and Preferences (rev. ed. 1940); 4 J. Moore et al., Collier on Bankruptcy $\Uparrow \Uparrow$ 67.29-67.43 (I4th ed. 1975); McLaughlin, Application of the Uniform Fraudulent Conveyance Act, 46 Harv. L. Rev. 404 (r933).

${ }^{2}$ Veil-piercing cases and equitable subordination are often treated together in courses on corporate law, and commentators have analyzed some of the interrelationships between these two doctrines. See generally the dialogue between Professors Landers and Posner: Landers, A Unified Approach to Parent, Subsidiary, and Affiliate Questions in Bankruptcy, 42 U. CHI. L. Rev. 589 (1975) [hereinafter cited as Landers I]; Posner, The Rights of Creditors of Affiliated Corporations, $43 \mathrm{U}$. Chr. L. Rev. 499 (1976); Landers, Another Word on Parents, Subsidiaries and Affiliates in Bankruptcy, 43 U. CHI. L. Rev. 527 (1976) [hereinafter cited as Landers II]. 
comparative analysis has performed a practical function. Since equitable subordination and piercing the corporate veil are, in large part, modes of overcoming the extraneous limitations of historically received fraudulent conveyance law, the judges who have initiated and developed these doctrines probably moved instinctively to portray them as applications of a respected tradition of equitable principles and rhetoric, rather than as a weakening of the ancient and substantial body of law of fraudulent conveyances. $^{3}$

The first section of the article will attempt to isolate the distinct but related purposes of fraudulent conveyance law a task sorely neglected in literally hundreds of cases applying that body of law. ${ }^{4}$ In light of these principles, the second section initially will focus on showing equitable subordination to be a functional substitute for fraudulent conveyance law under certain restrictive conditions. Then, by analyzing the legal system's response to situations that occur without one or more of these restrictions, I will uncover the origins and distinctive functions of the doctrine of equitable subordination. ${ }^{5}$ The third section will compare how the proposal of the Commission on the Bankruptcy Laws of the United States concerning the subordination of insider creditors' claims implements these principles. ${ }^{6}$ The fourth section shows the doctrine of piercing the corporate veil as expanding the ideals of equitable subordination and of fraudulent conveyance law. ${ }^{7}$ Finally, in the fifth section, common statutory restrictions on dividends are exposed as a weakened means of implementing the goals of fraudulent conveyance law. ${ }^{8}$

\section{The Normative Ideals of Fraudulent Conveyance Law}

The law of fraudulent conveyances, of which the Uniform Fraudulent Conveyance Act (UFCA) ${ }^{9}$ is the principal but not

But sustained analysis of the relationship of these two doctrines to fraudulent conveyance law is rare indeed.

${ }^{3}$ Note that this hypothesis does not require a belief that the judges who, for example, developed equitable subordination were consciously suppressing the doctrine's relationship to fraudulent conveyance law.

${ }^{4}$ See pp. 506-I 7 .

${ }^{5}$ See pp. $517-36$.

${ }^{6}$ See pp. $536-40$.

${ }^{7}$ See pp. $540-53$.

${ }^{8}$ See pp. 554-60.

${ }^{9}$ Because the UFCA is frequently cited in this article, it is here set forth in full:

Sec. I. Definition of Terms. In this act "Assets" of a debtor means property not exempt from liability for his debts. To the extent that any property is liable for any debts of the debtor, such property shall be included in his assets. 
exclusive embodiment, allows creditors to set aside certain transfers by debtors. Fraudulent conveyance law has a broad ap-

"Conveyance" includes every payment of money, assignment, release, transfer, lease, mortgage or pledge of tangible or intangible property, and also the creation of any lien or incumbrance.

"Creditor" is a person having any claim, whether matured or unmatured, liquidated or unliquidated, absolute, fixed or contingent.

"Debt" includes any legal liability, whether matured or unmatured, liquidated or unliquidated, absolute, fixed or contingent.

Sec. 2. Insolvency. (I) A person is insolvent when the present fair salable value of his assets is less than the amount that will be required to pay his probable liability on his existing debts as they become absolute and matured.

(2) In determining whether a partnership is insolvent there shall be added to the partnership property the present fair salable value of the separate assets of each general partner in excess of the amount probably sufficient to meet the claims of his separate creditors, and also the amount of any unpaid subscription to the partnership of each limited partner, provided the present fair salable value of the assets of such limited partner is probably sufficient to pay his debts including such unpaid subscription.

Sec. 3. Fair Consideration. Fair consideration is given for property, or obligation,

(a) When in exchange for such property, or obligation, as a fair equivalent therefor, and in good faith, property is conveyed or an antecedent debt is satisfied, or

(b) When such property, or obligation is received in good faith to secure a present advance or antecedent debt in amount not disproportionately small as compared with the value of the property, or obligation obtained.

Sec. 4. Conveyances by Insolvent. Every conveyance made and every obligation incurred by a person who is or will be thereby rendered insolvent is fraudulent as to creditors without regard to his actual intent if the conveyance is made or the obligation is incurred without a fair consideration.

Sec. 5. Conveyances by Persons in Business. Every conveyance made without fair consideration when the person making it is engaged or is about to engage in a business or transaction for which the property remaining in his hands after the conveyance is an unreasonably small capital, is fraudulent as to creditors and as to other persons who become creditors during the continuance of such business or transaction without regard to his actual intent.

Sec. 6. Conveyances by a Person About to Incur Debts. Every conveyance made and every obligation incurred without fair consideration when the person making the conveyance or entering into the obligation intends or believes that he will incur debts beyond his ability to pay as they mature, is fraudulent as to both present and future creditors.

Sec. 7. Conveyance Made With Intent to Defraud. Every conveyance made and every obligation incurred with actual intent, as distinguished from intent presumed in law, to hinder, delay, or defraud either present or future creditors, is fraudulent as to both present and future creditors.

Sec. 8. Conveyance of Partnership Property. Every conveyance of partnership property and every partnership obligation incurred when the partnership is or will be thereby rendered insolvent, is fraudulent as to partnership creditors, if the conveyance is made or obligation is incurred.

(a) To a partner, whether with or without a promise by him to pay partnership debts, or

(b) To a person not a partner without fair consideration to the partnership as distinguished from consideration to the individual partners.

Sec. 9. Rights of Creditors Whose Claims Have Matured. (I) Where a conveyance or obligation is fraudulent as to a creditor, such creditor, when his claim has matured, may, as against any person except a purchaser for fair consideration without knowledge of the fraud at the time of the purchase, or one who has derived title immediately or mediately from such a purchaser,

(a) Have the conveyance set aside or obligation annulled to the extent necessary to satisfy his claim, or

(b) Disregard the conveyance and attach or levy execution upon the property conveyed.

(2) A purchaser who without actual fraudulent intent has given less than a fair consideration for the conveyance or obligation, may retain the property or obligation as security for repayment. 
plicability, restricted neither to conveyances - since virtually all transfers of property, and, under the UFCA and under the Bankruptcy Act, the incurrence of obligations, are covered ${ }^{10}$ nor to fraud - since unfair transfers made without deceptive intent ${ }^{11}$ are included. Court opinions involving allegedly fraudulent transfers have not infrequently sounded muddled and uncertain notes because of a failure to discriminate among the various distinct ideals that this body of law seeks to implement. Although more than one of these distinct ideals are usually involved in actual cases, what these ideals are, and how closely they are related to the ideal underlying the law of preferential transfers, can be seen through an examination of four simple situations.

I. Debtor grants Friend a mortgage on his small factory in return for a loan of $\$ 160,000$, which Friend actually makes to Debtor. Debtor, wishing to discourage unpaid trade creditors having $\$ 30,000$ of claims from litigating them to judgment and seeking execution against the factory, prevails upon Friend to have the recorded mortgate recite that it secures a debt for $\$ 200,000$, which equals the well-known market value of the factory. ${ }^{12}$ The trade creditors' attorneys search the real estate records, discover and give credence to the false mortgage, and,

Sec. Io. Rights of Creditors Whose Claims Have Not Matured. Where a conveyance made or obligation incurred is fraudulent as to a creditor whose claim has not matured he may proceed in a court of competent jurisdiction against any person against whom he could have proceeded had his claim matured, and the court may,

(a) Restrain the defendant from disposing of his property,

(b) Appoint a receiver to take charge of the property,

(c) Set aside the conveyance or annul the obligation, or

(d) Make any order which the circumstances of the case may require.

Sec. II. Cases Not Provided for in Act. In any case not provided for in this Act the rules of law and equity including the law merchant, and in particular the rules relating to the law of principal and agent, and the effect of fraud, misrepresentation, duress or coercion, mistake, bankruptcy or other invalidating cause shall govern.

Sec. 12. Construction of Act. This act shall be so interpreted and construed as to effectuate its general purpose to make uniform the law of those states which enact it.

Sec. 13. Name of Act. This act may be cited as the Uniform Fraudulent Conveyance Act.

Sec. 14. Inconsistent Legislation Repealed. Sections ... are hereby repealed, and all acts or parts of acts inconsistent with this Act are hereby repealed.

${ }^{10}$ UFCA $\S \S \mathrm{I}, 4,6,7$; Bankruptcy Act $\S \S \mathrm{I}(30), 67 \mathrm{~d}(2)-(4)$, II U.S.C. $\S \S$ I (30), I07 (d) (2)-(4) (1970).

${ }^{11}$ See, e.g., UFCA $\S 4$; Bankruptcy Act $\S 67 \mathrm{~d}(2)(\mathrm{a})$, II U.S.C. $\S$ Iо7 (d) (2) (a) (1970)

${ }^{12}$ In order to protect himself from possible double-crossing on the part of Friend, Debtor has Friend sign a secret affidavit stating that as of the date after the recording he is owed only $\$ 160,000$ by Debtor, and the promissory note given by Debtor is in only this amount. Given the affidavit and the note, Friend's recovery would be limited to the $\$ 160,000$ in any legal action. 
knowing that Debtor has few assets other than the factory, become discouraged and cease pursuing Debtor.

Here, then, is a case of Ur-Fraud, that primeval fraud on creditors than which no greater can be thought. The transfer of the mortgage interest to Friend was known to be false, was intended to thwart legitimate creditors, and actually did so. The keynote of the evil is the actual deception or falsehood practiced on the trade creditors to their detriment. By hypothesis, Friend gave full and fair consideration for the extent of the mortgage interest that he could enforce against Debtor. Further, the mortgage interest that he obtained did not actually render Debtor incapable of satisfying the remaining creditors. The ideal offended is simply that of Truth: in connection with transfers of property rights to others, a debtor is forbidden to tell lies to his creditors that will lead to the nonsatisfaction of their claims. ${ }^{13}$

2. Debtor has reached the point where $\$ 100,000$ of her debts are due and payable, and her entire assets have a fair market value of the same dollar amount. Thinking that she would prefer that her husband and sister rather than her creditors get the benefits of her assets, she makes a deed of gift of all her possessions to those two fortunate relatives, and immediately delivers full and exclusive actual possession of the property to them, relinquishing any use or benefit from the transferred property. She makes no secret of the transaction or of her intentions: she reports the deed of gift in every conceivable recording office, and mails a copy by certified mail to each and every creditor, together with a detailed and psychologically accurate account of her motivations, purposes, and feelings toward her creditors. In this case, Debtor has made a transfer which would clearly be

${ }^{13}$ Finding fraudulent conveyance cases as to which we can be sure enough of the real facts to say that untruthful conduct and nothing else constituted the violation of duty to creditors is difficult. However, there are many cases under UFCA $\$ 7$ and similar rules in which the court decides on the basis of actual intent to defraud creditors in the sense of deceiving them, and notes that proof of facts violating other ideals is therefore unnecessary. See, e.g., Linder v. Lewis, Roca, Scoville \& Beauchamp, 85 Ariz. I18, 333 P.2d 286 (1958) (transferee misrepresented himself as purchaser for value; transferor's insolvency need not be proved); Cooper v. Cooper, r68 Cal. App. 2d 326, 335 P.2d 983 (r959) (putting title in name of woman friend to conceal ownership from former wife-creditor fraudulent; immaterial whether debtor rendered insolvent); Brown Packing Co. v. Lewis, ${ }^{85}$ Misc. 445, 58 N.Y.S.2d 443 (1943) (fair and adequate consideration irrelevant where there is no actual intent to defraud); Sheffit v. Koff, I75 Pa. Super. 37, roo A.2d 393 (1953) (showing of insolvency and lack of fair consideration not necessary under $\S 7$ ). 
voidable since it was made without fair and full consideration ${ }^{14}$ and she was insolvent immediately after the transfer. ${ }^{15}$

The ideal offended by Debtor in the above example is not that of truthful conduct toward creditors. Debtor has been completely open with her creditors and has never tried to deceive them, unless one wants to overstretch the notion of fraud by saying that, when she originally borrowed from her creditors, she "implicitly" promised to satisfy her legal obligations before her moral obligations and personal allegiances, that she has now failed to fulfill this promise, and that the failure is conclusive evidence that the promise was falsely and deceptively given. Instead, it is much simpler, and intellectually more honest, to recognize that another ideal is served by fraudulent conveyance law. The ideal can be captured by a cliche: be just before you are generous. ${ }^{16}$ The debtor has a moral duty ${ }^{17}$ in transferring his property to give primacy to so-called legal obligations, which are usually the legitimate, conventional claims of standard con-

${ }^{14}$ See UFCA $\S 3$ (definition of consideration).

${ }^{15}$ See UFCA $\S 4$.

The same provision would be used to undo certain related types of transactions, such as a sale of her property while debtor is insolvent to relatives or to innocent nonrelated parties at less than the property's fair equivalent value, whether the sale was deliberately designed to satisfy moral obligations or perceived allegiances to or preferences for the transferees or was simply a bad bargain on the transferor's part, resulting from ignorance and incompetence. In the absence of preemptive statutes concerning the legality of dividends, this same provision, or the one concerning transfers without fair consideration which leave a business with "unreasonably small capital," see UFCA $\S 5$, would also vitiate dividends paid to shareholders on the eve of a corporation's insolvency, as well as a myriad host of bargain transactions with corporate insiders - excessive salaries, purchases and sales at prices that are bargains to the insider, phony loans, and so forth.

${ }^{16}$ More specifically, this statement can be unpacked into a small family of commandments: Always act so that you can fulfill your legal obligations after any of the following: I) transferring property to satisfy moral obligations and personal allegiances; 2) making inadvertent or coerced transfers for less than full value; and 3) retaining property for your personal benefit or, in the corporate context, transferring it to your shareholders. Considerations of human dignity, as evidenced by the exemptions available in bankruptcy proceedings, now obviously limit the third commandment.

${ }^{17}$ I describe the duties inherent in fraudulent conveyance law as "moral" for at least two reasons. First, they are standards of right and wrong in debtorcreditor relationships, both commercial and personal, that have endured over many centuries and have governed extremely common transactions. The relation between debtors and creditors is as old as civilization, is only slightly less significant than relationships among family members, social classes, and races, has always occupied a substantial portion of the resources of legal systems, and has always been regulated in the commercial context by attitudes and emotions of a decidedly moral sort. Second, these duties are, I think, not really perceived as imposed by the statutes and cases which reflect them - as are many modern legal obligations but are perceived to be a part of normative custom. 
tract and tort creditors, as opposed to the interests of self, family, friends, shareholders, and shrewder or more powerful bargaining parties. ${ }^{18} \mathrm{I}$ will somewhat hesitantly refer to this as the normative ideal of Respect. ${ }^{19}$

3. Pierce is indebted to Twyne for $\$ 400$ and to $C$ for $\$ 200$. Pierce's nonexempt assets are worth only $\$ 300$. Suppose that Pierce, simply because Twyne is the first to ask that he do so and because he dislikes $C$, and for no other reason, transfers all of his property to Twyne. Suppose, contrary to the apparent facts in a similar, well-known case, ${ }^{20}$ that Pierce makes the transfer openly and with much publicity and fanfare, so that no deception of any sort is practiced on $C$, and that Pierce does not intend to and never does get a kickback of part of the transferred property or its use or any other kind of benefit from Twyne. Assume also that Twyne's claim is a completely valid, unobjectionable, due and payable, legal obligation of the most conventional sort.

Pierce's transfer to Twyne does not run afoul of the normative ideals of Truth and Respect toward creditors because Pierce has fully and truthfully described the transaction and has given primacy to his legal obligations. It is, however, objectionable for a debtor to satisfy the claims of just one creditor at a time when he lacks sufficient assets to meet his other legitimate and conventional legal obligations. A preferential payment of this sort hinders pro tanto the interest of all the other creditors. In such a situation, a debtor should deal equally with all his creditors. I will dub this principle the ideal of Evenhandedness toward creditors, with the understanding that in using this term the connotation is of equality of treatment of legal obligations

\footnotetext{
${ }^{18}$ Fraudulent conveyances of the sort under discussion may be buried amid obscuring factors, and it thus requires judicial imagination to see through the disguises and lawyerly caution to anticipate the possibilities. For instance, a bootstrap acquisition plan may give rise to voidable fraudulent conveyances when the acquired company later distributes assets, either directly to the seller or to the stock purchaser for use in meeting obligations to the seller, when the company is insolvent or possessed of small capital. E.g., Steph v. Branch, 255 F. Supp. 526 (E.D. Okla.), aff'd., 389 F.2d 233 (roth Cir. 1968) ( $A$ sold stock in corporation $X$ to $B$, taking note for most of purchase price; parties have $X$ discharge $B$ 's obligation by furnishing free materials to $A$.)

${ }^{19}$ Were the connotations not so challengingly disturbing, I would label this ideal the principle of fealty to creditors, since the term "fealty" describes the sort of primary allegiance that is apparently called for by the law. Another possible label, "loyalty," has been preempted for use in the quite parallel context of a corporate director's duty to his corporation: the director must avoid abusive self-dealing and other conduct which puts his own interests, or that of a particular group of shareholders, above the interests of the shareholders as a whole.

${ }^{20}$ Twyne's Case, 3 Coke 8ob, 76 Eng. Rep. 809 (Star Chamber r60r).
} 
in connection with liquidation proceedings. ${ }^{21}$ Evenhandedness, in its fullest expression, has two aspects. Whenever a debtor is or is about to become insolvent and thus unable to satisfy all his creditors in full, the debtor should refrain from preferring one creditor over another. Similarly, in such cases creditors should refrain from seeking such a preference. In either instance, transfers resulting in better than equal treatment on the eve of liquidation proceedings should be undone - and may actually be undone in bankruptcy proceedings as voidable preferential transfers.

4. Debtor, who owns 250 shares of stock, sold those shares to her husband for full value in illiquid assets. She was not insolvent at the time of the sale but the stock had been her only liquid asset and as a result of the transaction she had no assets which creditors could easily reach. She made the transfer for the purpose of hindering her creditors but did not deceive them. This transaction would be avoided under the open-ended language of the UFCA, ${ }^{22}$ which covers transactions made with actual intent to hinder or delay creditors. ${ }^{23}$

Although the debtor intends and accomplishes a transfer leading to a hindering of her creditors, this case does not strictly offend the ideals of Truth, Respect or Evenhandedness as developed above. The scheme involves no actual deception, for she has truthfully informed all her creditors of the transaction. Moreover, the transfer of the shares is not for less than their fair value, nor does the transfer leave the debtor insolvent, so the transfer does not violate the ideal of Respect. Finally, the scheme results in no preference of any preexisting creditor over the others. Hence, one could say that there may be transactions which are not offensive of the above ideals in their normal applications, but which are yet fraudulent conveyances because they violate the more general expression of the ideal of which all three of the subsumed ideals are specifications. The general ideal might be described as that of Nonhindrance of the enforce-

${ }^{21}$ The ideal of Evenhandedness is not always adopted, especially in piecemeal liquidations, when individual creditors separately levy upon and exhaust the debtor's property, as opposed to collective liquidations such as dissolution and winding up under state corporate law, straight bankruptcy proceedings under federa] law, liquidating receiverships, and assignments for the benefit of creditors. The ideal is, however, sometimes enforced, as among creditors of the same class, in proceedings looking toward reorganization rather than liquidation of the distressed debtor - for instance, in reorganizations under Chapter $\mathrm{X}$ of the Bankruptcy Act, II U.S.C. $\$ \S$ IOI-276 (1970).

22 See UFCA $\$ 7$.

${ }^{23}$ This hypothetical is based on the facts in Klein v. Rossi, 25 I F. Supp. I (E.D.N.Y. 1966). 
ment of valid legal obligations against oneself, in connection with transfers of one's property.

In summary, then, fraudulent conveyance law embodies a general ideal, in connection with a debtor's transfers of property rights and incurrences of new obligations, of Nonhindrance of creditors. This vague ideal is made operational through the effectuation of the more specific ideals of Truth, Respect, and Evenhandedness as well as a general, residual prohibition of conduct which hinders creditors in attempting to satisfy their claims.

Thus far, Evenhandedness has been conceived of as one of three particular duties derived from the general duty of Nonhindrance, because a violation of the duty of Evenhandedness operates to hinder the nonpreferred creditors. It is also possible, however, to view Evenhandedness as a policy independent of, and on a par with, a general ideal of Nonhindrance, and this aspect of the policy has led to its development as a separate topic. While like the other two ideals Evenhandedness specifies the moral duties of a debtor to his creditor, Evenhandedness is also the ideal behind what is referred to as the law of voidable preferences and many cases assume or state explicitly that a preference is not a fraudulent conveyance. ${ }^{2+}$ However, the fact situations in many fraudulent conveyance cases suggest that those cases might have been treated equally as well as instances of voidable preferences. ${ }^{25}$

For example, one of the great ironies of legal history is that Twyne's Case ${ }^{26}$ which is widely regarded as the fountainhead of the modern Anglo-American law of fraudulent conveyances, ${ }^{27}$ does not, as presented in the reports, clearly involve anything more than a preference. The transaction offended the ideal of Evenhandedness, which was not then an ideal that the common law of individual collection efforts respected, but it is not clear that it offended the ideals of Truth and Respect in any relevant way. The facts, which are roughly similar to those in the third example discussed above, do appear to include the circumstance that Pierce's transfer to Twyne was secret. But why a transaction which would be a mere nonvoidable preference if done openly should become a voidable fraudulent conveyance because done secretly is not at all clear, either from the report of the case

${ }^{24}$ E.g., Dean v. Davis, 242 U.S. 438 (I917) ; Coder v. Arts, 213 U.S. 223,242 (rgo9); Pope v. National Aero Fin. Co., 236 Cal. App. 2d 722, 46 Cal. Rptr. 233 (1965); Johnson v. O'Brien, 275 Minn. 28, 144 N.W.2d 720 (1966).

${ }^{25}$ See, e.g., Bullard v. Aluminum Co. of America, 468 F.2d in (7th Cir. 1972).

${ }^{26}{ }_{3}$ Coke 8ob, 76 Eng. Rep. 809 (Star Chamber r60I).

${ }^{27}$ See C. Corman, Commercial Law, Cases and Materials 187 (1976). 
or in logic. ${ }^{28}$ Perhaps the secrecy led $C$ to pursue his collection efforts longer than he would have had he known of the preference, and thus to waste money. This possibility, it seems, could have been covered quite adequately by letting $C$ recover the pointless expenses, rather than condemning the whole transfer to Twyne as a criminal act. It might conceivably be that the key to the case was that Pierce was satisfying some moral obligation to Twyne, for the report is full of apparently irrelevant remarks concerning that theme. ${ }^{29}$ More likely, and supported by inferences from the report ${ }^{30}$ is the hypothesis that Pierce violated the ideal of Truth because he did not really transfer the entire amount of his property, but under a kickback arrangement with Twyne (who was apparently too slow of foot at that point to win his race against $C$ via the use of judicial process) kept the use and benefit of certain property. Pierce was to keep some of his assets, though insolvent; Twyne was to obtain a larger percentage of his claim than if he resorted to legitimate collection procedures; and both were to defraud $C$ in his collection efforts by pretending that Pierce no longer had any assets. The case may actually be understandable, then, as a case similar to the first example above, which involved actual, detrimental deception. $^{31}$

Despite their essential kinship, the fact that fraudulent conveyances and voidable preferences have emerged as distinct legal

${ }^{28}$ For an interesting but unsuccessful attempt to argue that it may be a fraudulent conveyance to attempt to conceal a preference, see In re Cushman Bakery, 526 F.2d 23, 30-34 (rst Cir. 1975), cert. denied, 44 U.S.L.W. 3586 (April 20, 1976 ).

${ }^{29} 76$ Eng. Rep. at $814-15,822-23$.

30 " $[\mathrm{N}]$ otwithstanding that [the deed of gift of all Pierce's goods and chattels to Twyne, in satisfaction of his debt] Pierce continued in possession of the said goods, and some of them he sold; and he shore the sheep, and marked them with his own mark . . . "76 Eng. Rep. at 8II. "The donor continued in possession, and used them as his own; and by reason thereof he traded and trafficked with others, and defrauded and deceived them." 76 Eng. Rep. at 812-I3. "[N] otwithstanding here was a true debt due to Twyne, and a good consideration of the gift, yet it was not within the proviso of the said Act of $\mathrm{I}_{3}$ Eliz.... it is not bona fide, for no gift shall be deemed to be bona fide within the said proviso which is accompanied with any trust ... [and] continuance of the possession in the donor, is a sign of trust." 76 Eng. Rep. at 814.

Twyne's case is, of course, the fountainhead of doctrines of fraudulent retention of possession, the ultimate development of which was to plague the development of the law governing security interests in personal property left in the debtor's possession. Indeed, a good number of the fraudulent conveyance cases decided under the "actual fraud" rubric involve transfers of property without a change of possession. See 2 G. Glenn, supra note I, chs. XVIII(B)-XX (rev. ed. I940).

${ }^{31} 76$ Eng. Rep. at 823 . 
doctrines has significant consequences. While both fraudulent conveyances and preferences are voidable in bankruptcy, ${ }^{32}$ preferences can be avoided only by the bankruptcy trustee while fraudulent conveyances are voidable under state law at the behest of individual creditors. ${ }^{33}$ Similarly, whereas preferences must have occurred within four months before the filing of the bankruptcy petition in order to be voidable,$^{34}$ fraudulent conveyances which took place one year or possibly more before filing ${ }^{35}$ may be set aside. And the lists of technical requirements concerning the two branches of law could be differentiated at point after point. ${ }^{36}$

Perhaps the key to the existence of the two great, "separate" branches of the law concerning the debtor's moral duties to his creditors is that the ideal of Evenhandedness has never been considered as important to the functioning of the commercial system, which constitutes the essence of our culture, as the ideals of Truth and Respect. Evenhandedness, therefore, has been relegated in part to a separate doctrinal category, where it can be diluted and adjusted by limited implementing rules, without

${ }^{32}$ See Bankruptcy Act $\S \S 60,67$ d, 70e, ir U.S.C. $\$ \S 96$, I07(d), I Io(e) (1970).

${ }^{33}$ Indeed, in the area of piecemeal liquidation of insolvent estates, state law not only allows debtors to give creditors preferred treatment but permits creditors to seek to obtain it forcibly, by selfconsciously rejecting the principle of equal treatment in favor of the "grab" principle: the guiding notion is that diligence in the use of individual coercive collective procedures should be rewarded, so that the swiftest of wing - he who, or it which, first gets a judicial lien — should be first satisfied. See, e.g., Cal. Civ. Code Ann. $\$ 3432$ (I970).

${ }^{34}$ See Bankruptcy Act $\$ 60 a($ I), I I U.S.C. $\$ 96(a)($ I) (I970) (definition of preference). Exceptions may occur when the trustee, relying on $\S 70$, invokes state law to avoid a preference. See 4A J. Moore et al., Collier on Bankruptcy $\llbracket 70.88$ (I4th ed. I975).

${ }^{35}$ Most transfers and obligations voidable under $\$ 67$ d, II U.S.C. $\$ 107$ (d) (1970), must have occurred within one year of the filing of the bankruptcy petition. See $\S 67 \mathrm{~d}(2),(4)$, I I U.S.C. § Io7(d) (2), (4) (I970). But see § $67 \mathrm{~d}(3)$, I I U.S.C. $\S$ Io7(d) (3) (I970). Transfers and obligations avoided by a trustee in bankruptcy under $\S 70$, II U.S.C. \$ I IO(e) (1970) may have occurred much further in the past, depending on the applicable state statute of limitation. See 4A J. Moore ET AL., supra note $34, \pi 70.7 \mathrm{I}$ at $80 \mathrm{I}$.

${ }^{36} \mathrm{An}$ antecedent debt equal to the value of the transferred property can be fair consideration for fraudulent conveyance purposes; a transfer can be a preference only when it is given for or on account of an antecedent debt. A fraudulent conveyance may be voidable, at least in part, despite the transferee's complete good faith; a preference is voidable under $\S 60 \mathrm{~b}$ only if the preferee had, at the time of the transfer, reasonable cause to believe that the debtor was insolvent. Transfers may sometimes be voidable fraudulent conveyances even when the transferor is not afterwards insolvent; a preference can only be made by an insolvent debtor. Diferent definitions of "insolvency" govern the two contexts. Fraudulent conveyance rules apply to transfers made and obligations incurred; preference rules obviously apply only to transfers. 
affecting the other two ideals. This strategy is reflected in such tired, and not entirely accurate or meaningful, saws as the one that there is nothing morally or legally "wrong" with giving or seeking a preference, though fraudulent conveyances should not be counselled by the debtor's or the creditors' attorneys. ${ }^{37}$ It is also reflected, of course, in the enormous number of exceptions made to the principle of equal treatment of creditors in bankruptcy-exceptions ranging from security interests through statutory priorities to contractual and other forms of subordination among creditors. ${ }^{38}$

The ideals of Nonhindrance, including the special evolution of Evenhandedness in the voidable preference doctrine, have been presented above in a rather tidy and purified form. In actual implementation, the ideals are often balanced against other objectives of the legal system, especially that of fairness toward the debtor's transferee. As is evident from a close reading of the UFCA, the good faith or absence of actual fraudulent intent of the transferee may have a bearing on the extent of the creditor's recovery. ${ }^{39}$ Though it does not seem unduly harsh to ask an innocent transferee to disgorge the amount by which he has beat the market when he paid less than fair value for transferred property, given that the transferor's innocent creditors would otherwise lose that amount, to go further would be punitive and unfair. Moreover, in some old or odd cases the transferee's innocence may prevent recovery entirely, and under dividend statutes, ${ }^{40}$ the transferee's status as innocent public shareholder may protect him entirely. Furthermore, in actions to avoid preference under Bankruptcy Act section 6ob, the preferee must be shown to have had reasonable cause to believe that the debtor was insolvent at the time of the transfer. ${ }^{41}$

In addition, the legal system, in implementing the ideals of Nonhindrance, has had to go beyond the fraudulent conveyance doctrine, embedding Nonhindrance principles in other branches

${ }^{37}$ As the Supreme Court put it, "The Statute recognizes the difference between the intent to defraud and the intent to prefer, and also the difference between a fraudulent and a preferential conveyance. One is inherently and always vicious; the other innocent and valid, except when made in violation of the express provisions of a statute. One is malum per se and the other malum prohibitum, - and then only to the extent that it is forbidden." Van Iderstine v. National Discount Co., 227 U.S. 575, 582 (I9I3).

${ }^{38}$ See generally 3 A J. Moore et al., Collier on Bankruptcy $\|$ Iा 64.0I-64.70I (I4th ed. 1975).

${ }^{39}$ See UFCA $\$ 33,9(2)$.

${ }^{40}$ See pp. 554-60 infra.

${ }^{41}$ However, in another context involving Evenhandedness - a proceeding to declare a judicial lien invalid under the Bankruptcy Act $\$ 67 \mathrm{a}$ - this is not a prerequisite. 
of the law. In theory, the norms of Nonhindrance could be effectuated through three radically different modes. First, the ideals could be expressed as a system of transactional rules; decision of cases under the rules would necessitate examination of specific transactions and proof of a violation of an ideal in each transaction. Fraudulent conveyance law fits this mode. The second mode of implementation is the gestalt approach: when transactions are complex or involve elements that are not normally covered under the transactional mode, this approach would permit a court to apply a remedy, albeit a crude one, to correct a pattern of fraudulent transfers or obligations that may reasonably be inferred. This mode of implementation is, it will be argued in Part II, exemplified by the doctrine of equitable subordination. Finally, the ideals could be embodied in a system of preventive rules. It is urged that the rule of automatic subordination proposed by the Bankruptcy Commission and discussed in Part III below is an instance of this third mode of implementation. Thus, the next two parts focus on the relationships between these three modes of implementation of the ideals of Nonhindrance.

\section{Fraudulent Conveyances and Equitable Subordination}

Compared to the law of fraudulent conveyances, the doctrine of equitable subordination is more modern, less widely adopted by legal systems and basically applicable to a much narrower class of situations - federal bankruptcy proceedings involving debtors owned or controlled by persons who are also creditors of the bankrupt. ${ }^{42}$ Typically, application of the doctrine of equitable subordination leads to the result that the creditor claims of an insider or controlling party - a parent corporation, a sole shareholder, or a shareholder who in relation to other shareholders owns "debt" claims against the insolvent corporation in the same

${ }^{42} \mathrm{~A}$ leading article on equitable subordination is Herzog and Zweibel, The Equitable Subordination of Claims in Bankruptcy, I5 Vand. L. Rev. 83 (I96I). See also Ashe, Subordination of Claims, 84 Banking L.J. 778 (I967); Gleick, Subordination of Claims in Bankruptcy Under the Equitable Power of the Bankruptcy Court, I6 Bus. LaW. 6II (I96I); Kennedy, Insolvency and the Corporate Veil in the United States, in Canadian and Foreign Law Research Centre: Proceedings of the Eighth International Symposium on Comparative Law 233 (1971); Riemer, Claims Against Bankrupt Corporations Based on Advances by Controlling Shareholders or Parent Corporations, 73 CoM. L.J. 273 (1968); Note, Parent Corporation's Claims in Bankruptcy of Subsidiary: Effect of Fiduciary Relationship, 54 HaRv. L. REv. I045 (194I). The standard reference work's treatment appears in $3 \mathrm{~J}$. Moore et aL., Collier on Bankruptcy $₫ 57.14$ (i4th ed. rev. I976) and 3A J. Moore et AL., supra note 38, II 63.06, 63.08, 65.06. 
proportion as his stock ownership - are subordinated to those of bona fide outside creditors. The subordination is not automatic in our present law but is said to turn on the presence of fraudulent conduct by the insiders, mismanagement of the insolvent corporation, or inadequate capitalization of the corporation. ${ }^{43}$

In this part, first the functional equivalence between fraudulent conveyance law and equitable subordination doctrine in implementing the normative principles previously discussed will be illustrated by dealing with a large class consisting of fraud cases and most of the so-called mismanagement cases. After discussing why the development of equitable subordination was necessary, a small number of mismanagement cases, which might be described as "pure waste" cases not involving fraudulent transfers of any sort, will then be isolated. My comments will attempt to show that equitable subordination serves a function with respect to these situations that complements that served with respect to the first category of fraud and mismanagement cases. The inadequate capitalization cases will receive special consideration.

\section{A. The Area of Functional Equivalence Between Fraudulent Conveyance Law and Equitable Subordination Doctrine}

Analysis of a few examples will show that, given three restrictive conditions, equitable subordination is principally a functional substitute for fraudulent conveyance law. ${ }^{44}$ These conditions are: (a) a simple situation, which is here defined as one involving only one tainted transaction by the bankrupt corporation at the instance of controlling parties; (b) a world in which corrective legal responses to tainted transactions take place without transaction costs; ${ }^{45}$ and (c) a policy decision that any rule attempting

${ }^{43}$ Herzog and Zweibel classify the subordination cases into six categories. See Herzog \& Zweibel, supra note 42, at 90-II2. With a few exceptions, the cases under three of their headings (fraud, fiduciary relationship, and instrumentality and alter ego cases) appear upon analysis of their facts to suggest actual or constructive fraud. See pp. 526-27 \& notes 54 and 63 infra. One of their categories, the capital contribution cases, explicitly implicates the inadequate capitalization issue. Their other two categories are of tangential interest only. The "consensual subordination" cases simply involve courts in the process of finding or inferring an intent by a creditor to subordinate his claim to those of others - such cases are not within the ambit of "equitable subordination" as I construe the term. Finally, the remaining cases concern claims tainted by illegality.

${ }^{44}$ In fact, under these restrictive conditions, equitable subordinations may occasionally serve as a functional substitute for a few other legal doctrines, such as that which permits a derivative suit against corporate directors and officers for waste of corporate assets.

45 Transaction costs, and in particular the expenses of administering the bank- 
to undo the effects of a controlling creditor's influence should seek to accomplish the goal of corrective justice. The last condition may be accomplished by acceptance of a certain one of three facially plausible interpretations of equitable subordination doctrine. For convenience, the three possibilities will be labelled the Full Subordination Rule, the Offset Rule, and the Constructive Distribution Rule. Under the Full Subordination Rule, invocation of the doctrine automatically and invariably implies full subordination of all creditor claims of the controlling party, and nothing else. ${ }^{46}$ As a result, the insider may in some cases be penalized in an amount greater than the unjust advantage he reaped from his controlling position. The second and third interpretations are supposed to be corrective but not punitive the controlling party is subordinated only to the extent of the unfair advantage taken of the corporation. ${ }^{47}$ Under the Offset Rule, the nonpunitive objective is construed to mean that the amount of the unjust benefit will be deducted from the insider's legitimate creditor claim and then the estate will be distributed pro rata. ${ }^{48}$

rupt estate are ignored throughout this initial phase of the analysis because they do not significantly affect the thrust of the argument. The true importance of transaction costs is explored in section II.B. infra. As will become apparent as the analysis unfolds, the restrictive condition of a simple situation is principally important for legal doctrine because complex situations may entail very high transaction costs by making proof and analysis of particular facts quite expensive or impossible. In a sense, condition (a) is included in condition (b). However, I think it useful to treat the transaction costs generated by complex situations seperately. The kinds of transaction costs which I intend to negate by condition (b) will appear from the discussion in section II.B. infra.

${ }^{46} \mathrm{I}$ assume throughout the logical implication of the Full Subordination Rule, as defined in text, that one is not treating equitable subordination as a remedy in addition to the fraudulent conveyance action. The additive view is suggested rarely, if at all, in the cases. In one cryptic case, after holding prebankruptcy secured transactions void as preferences and fraudulent conveyances, the referee and court subordinated the remaining claim that the creditor did prove because of "the "insider' or alter ego nature of this matter." In re Sales Incentives Corp., 327 F.Supp. 937, 940 (D.R.I. I97I). The case may be an example of using equitable subordination as a response to inadequate initial capitalization, a problem not dealt with by traditional fraudulent conveyance law, see section II.C. infra. See also the discussion of In re Process-Manz in note 63 infra.

${ }^{47}$ The power of equitable subordination

should not operate to take away anything punitively to which one creditor is justly entitled in view of the liquidation finality, and bestow it upon others, who in the relative situation have no fair right to it. It can therefore ordinarily go no farther than to level off actual inequitable disparities on the bankruptcy terrain for which a creditor is responsible, to the point where they will not create unjust disadvantages in claim positions and liquidation results.

In re Kansas City Journal-Post Co., I44 F.2d 79I, 800-oI (8th Cir. 1944). See also Prudence Realization Corp. v. Geist, 3 I6 U.S. 89, 97 (1942) ; Farmers Bank v. Julian, 383 F.2d 314, 323 (8th Cir.), cert. denied, 389 U.S. IO2I (I967).

${ }^{48} \mathrm{I}$ have not found any case which clearly applies the Offset Rule. It is 
Finally, under the Constructive Distribution Rule the pro rata shares would be computed as if the tainted transaction had not occurred and the controlling party is then considered to have already received an anticipatory distribution in the amount of his unjust benefit. ${ }^{49}$ Although the case law and commentary on equitable subordination remedies have failed to properly distinguish

analyzed here because, in numerous conversations with practicing lawyers about what a nonpunitive rule of equitable subordination would be, I have heard the Offset Rule, or something like it, suggested. This interpretation is discussed here since it may be useful to point out that this Rule is one of those ideas that may seem solid upon first perception but dissolves with a little analysis.

${ }^{49}$ Again, I know of no case which clearly expresses the rule in question. Cases enunciating the nonpunitive ideal generally do not present the issue squarely. In In re Kansas City Journal-Post Co., I44 F.2d 79I, 800-or (8th Cir. I944), for example, the trustee had brought a separate action to recover an inequitable payment to the controlling party, and the Court of Appeals simply upheld the district court's reversal of the referee's subordination of the controlling party's much larger, and properly acquired, creditor claim. The result is nonpunitive but the court was not called upon to choose any mode of subordination; given the separate action it could prevent a penalty by refusing to subordinate.

Given the thesis advanced herein, see sections II.B. and C. infra, as to the reasons for the existence of equitable subordination doctrine - one of which is the desideratum in complex cases of providing a blanket analysis and a crude remedy it is not at all surprising that equitable subordination cases contain no or weak discussions of remedial alternatives, or that many of them simply apply a Full Subordination Rule despite the notion that equity is simply geared to righting wrongs, not punishing them.

Most of the cases discussed in note 63 infra assumed or stated without discussion that the remedy against the controlling party was (or would have been) total subordination, or perhaps disallowance. Commentators have been more selfconscious in their discussion of remedies, and less happy with widespread use of full subordination. One acknowledges that in complex cases, like Deep Rock, discussed at pp. 526-27 infra, the controlling parties' claims have been totally subordinated (though noting that lower courts and the Securities and Exchange Commission have approved compromises), but asserts that "[i]n the absence of complexity only so much of the parent's claim will be subordinated as is necessary to make the injured subsidiary whole." Note, The Deep Rock Doctrine: Inexorable Command or Equitable Remedy?, 47 Colum. L. Rev. 800, 808-o9 (1947). Another notes the argument that the test should be "discriminating and should penalize the parent only for advances which are themselves unfair," such as one that an informed outside lender would not have made. Note, supra note 42 , at 1047. See also Rembar, Claims Against Affiliated Companies in Reorganization, 39 Colum. L. REv. 907, 9I6 (1939). Another suggests that in an inadequate initial capitalization or a mismanagement case there should ideally be subordination of the controlling party's claim only to the extent of the inadequacy or mismanagement, but that where there is inadequate capitalization plus inequitable conduct in an extreme (complex) case, or where no more accurate remedy appears practical, there should be total subordination. Krotinger, The "Deep Rock" Doctrine: A Realistic Approach to Parent-Subsidiary Law, 42 Colum. L. Rev. II24, II32-33, II35, II38 (I942). Herzog and Zweibel, supra note 42 , at $85-88$, are concerned with the infrequently consequential distinction between subordination and disallowance, and generally argue for the former. 
among these three rules, a comparison of their effects in the examples which follow indicates that the determination of which rule to apply has significant consequences for the remedy in the case. Moreover, it will be shown that the Constructive Distribution Rule best accomplishes the goal of corrective justice posited above.

I. The Alpha Situation: Estate Insolvent Apart from Tainted Transaction. Milkable Corporation $(M)$, which is controlled by a sole stockholder $(S)$, owned assets with a fair salable value of $\$ 150$. Previously, it had entered into a bona fide borrowing transaction at market interest rates with $S$, who thus became a creditor with a $\$ 100$ claim. It had also bought goods on credit from a supplier who thus became an outside creditor $(O C)$ with a claim of $\$ 100$. There were and are no other creditors. In the absence of transaction costs, if, without more, $M$ were to go into bankruptcy, $S$ and $O C$ would each receive $\$ 75$. Let us refer to $S$ 's $\$ 75$ share in the bankrupt estate under such innocent conditions as S's Just Share of the estate. This set of facts will be referred to as the Alpha Situation.

Suppose, however, that in fact $S$ received a gratuitous or unfair benefit (in general, an Unjust Benefit) from $M$ within some reasonable period before bankruptcy. The exact form in which $S$ obtains a benefit without paying full consideration to $M$ is not important: $S$ may have caused $M$ to pay $\$ 70$ for services that $S$ did not perform; $M$ may have declared the money as a dividend to $S ; S$ may have sold goods to $M$ at a price $\$ 70$ in excess of the market price, or $M$ could have sold goods to $S$ at $\$ 70$ less than the market price; or $S$ could have used the company's car or yacht for his personal use without compensation to the company. Further; the creation of the legitimate amount owed $S$ and the illegitimate transfer of benefit to him may have occurred in the same transaction, for example, a credit sale of goods by $S$ to $M$ for $\$ 170$, where the market price was only $\$ 100$. All that is required at this point is an analytical ability to separate out $S$ 's legitimate claim from the component of unjust benefit conferred.

If $M$ 's estate is distributed in bankruptcy without any attack on the $\$ 70$ benefit paid to $S$ for bogus services, $S$ and $O C$, having equal creditor claims of $\$ 100$, will each receive $\$ 40$, or one half of the assets of the estate remaining after the payment for bogus services $(\$ 150-\$ 70=\$ 80)$, and $S$ will keep his $\$ 70$. As a result, $S$ will have obtained $\$ 110$ and $O C$ will have obtained $\$ 40$. If the transfer for bogus services had not occurred, however, each would have received one half of the company's $\$ 150$ in assets, that is, his $\$ 75$ Just Share. 
Obviously, the legal system is called upon to make some sort of response to the bogus payment for services since such payments by a debtor to a controlling person at the latter's direction violate the principle of Respect. Intuitively, if the aim of the ideal legal response to $S$ 's conduct is not punitive - a proposition that will later be examined and, in general, defended - its task is to construct a doctrine that will lead to the result that would have occurred upon liquidation of $M$ if $S$ had not engaged in the wrongful conduct. $S$, in other words, should wind up with neither more nor less than his Just Share of $\$ 75$. How the parties will actually fare under the major remedial tools now available, fraudulent conveyance law and equitable subordination doctrine, turns out to depend on which of the three plausible interpretations of equitable subordination is employed, and whether the amount of the Unjust Benefit is less than or greater than $S$ 's Just Share of the estate. The following paragraphs will illustrate these relationships.

(a) Where amount of Unjust Benefit to the controlling party is less than his Just Share. - Consider the Alpha Situation when the amount of the payment to $S$ for bogus services is, as supposed above, $\$ 70$. Fraudulent conveyance law is precisely suited to correcting such bogus payments. ${ }^{50}$ The trustee $(T)$ in bankruptcy could sue $S$ to recover $\$ 70$ for the bankrupct estate..$^{51}$ In particular, he might invoke UFCA $\S 4$, since the transfer to $S$ was without fair consideration while the estate was insolvent. The estate, now augmented to $\$ 150$, would be divided equally

${ }^{50}$ The text makes fraudulent conveyance law appear neater than it is. In a case where the transferee gave some but not fair consideration for the benefit conferred upon him, the analysis is more complicated. If the transferee acted "without actual fraudulent intent" he may retain the property transferred as security for return of the amount paid or consideration given. See Bankruptcy Act $\S 67 d(6)$, I I U.S.C. $\$$ I07(d) (6) (1970); UFCA $\$ 9(2)$. Usually, however, a controlling party who makes himself transferee for inadequate consideration will have displayed actual fraudulent intent within the meaning of these provisions, with the result that the transfer will be voided in toto. This is not in theory a punitive result, however, since after surrendering the transferred property he can then prove an unsecured claim in bankruptcy for the amount of the consideration actually paid. See 4 J. Moore ET AL., supra note $34, \| 67.4 \mathrm{I}$ at 605,597 n.57. On the other hand, this result is punitive in practice when compared to the happier fate of a controlling party who in one trasaction with his corporation paid equal value for a transfer and in a second transaction simply caused a transfer without giving any consideration: upsetting only the second transaction, as seems feasible under a fraudulent conveyance approach, still leaves him with the benefit transferred in the first transaction, instead of with a provable claim on which he can hope to obtain only a few cents on the dollar. In other words, the rules work more harshly on those who integrate unfairness into their regular dealings than on those who keep their self-dealing clear and distinct.

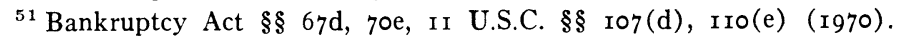


between $O C$ 's and $S$ 's legitimate claims, and each would therefore receive $\$ 75$.

What would happen if $T$ decided to invoke the doctrine of equitable subordination against $S$ is less clear, for the answer depends upon which interpretation of that doctrine one selects. If the Full Subordination Rule were selected, $T$ would bring no action for recovery of any amount from $S$, but would simply distribute the bankrupt estate, a non-augmented $\$ 80$, first in satisfaction of $O C$ 's $\$ 100$ claim. There being no remainder, $S$ winds up with $\$ 70$, the amount of the bogus payment, which is $\$ 5$ less than his Just Share. Thus, when the Unjust Benefit is less than the Just Share, $S$ has been penalized relative to what he would have received were the law aimed solely at undoing his wrong. Under the Offset Rule, the $\$ 70 \mathrm{~S}$ has already received would be deducted from his $\$ 100$ claim and the $\$ 80$ remaining in the estate would be divided between $O C$ (who had as yet received no satisfaction of his $\$ 100$ claim) and $S$ on a $100 / 30$ basis, yielding $\$ 61.54$ for $O C$ and $\$ 18.46$ for $S$ who, taking into account his prior $\$ 70$ benefit for bogus services, wirds up with $\$ 88.46$. Since the result for $S$ is $\$ 13.46$ better than his Just Share, the Offset Rule leads in this instance to undercorrection of his misconduct. Finally, under the Constructive Distribution Rule $T$ would deem the estate to contain $\$ 150$, would compute each of the two creditors' shares as being $\$ 75$, and would deem $\$ 70$ of $S$ 's share to have already been paid. Of the $\$ 80$ actually left in the estate, $O C$ would therefore obtain $\$ 75$ and $S$ would receive $\$ 5$. The ultimate result is that $S$ obtains exactly his Just Share which is the result that a fraudulent conveyance action would have reached.

b. Where amount of Unjust Benefit to the controlling party is greater than his Just Share. - Consider now the Alpha Situation when the amount of the payment for bogus services was $\$ 80$. If $T$ brings a fraudulent conveyance action this amount will be recovered for the bankrupt estate and $S$ will wind up receiving his Just Share, as in the preceding case.

Under the Full Subordination Rule, $T$ simply attempts to satisfy $O C$ 's claim first. $O C$ receives the amount of the nonaugmented estate, $\$ 70$, while $S$ keeps his $\$ 80$ prior payment. Since $S$ 's Just Share is only $\$ 75, S$ 's having received the bogus payment has netted him an unfair advantage even after the application of the doctrine of equitable subordination. In contrast to the facts discussed in $a$, the Full Subordination Rule now leads to undercorrection rather than overcorrection.

Given the Alpha Situation and an Unjust Benefit of $\$ 80$, the second interpretation of equitable subordination, the Offset Rule, 
again leads to undercorrection. $S$ 's $\$ 100$ claim is reduced by the amount of his unfair advantage to $\$ 20$ and the non-augmented estate of $\$ 70$ is then distributed to $O C$ and $S$ on a $100 / 20$ basis. $O C$ thus receives $\$ 58.33$. S receives $\$ 11.67$, which, together with the prior payment of $\$ 80$, gives him $\$ 16.67$ more than his Just Share.

Whether the third interpretation, the Constructive Distribution Rule, will again, as in subsection $(a)$ above, avoid both undercorrection and penalties depends on the resolution of a new ambiguity. $T$ deems the estate to contain $\$ 150$, as it would absent the payment for bogus services, computes $O C$ 's and $S$ 's shares to be $\$ 75$ each, and deems $S$ already to have received a bankruptcy distribution of $\$ 80$ (the amount of the Unjust Benefit). The question remaining is whether $T$ will regard this constructive bankruptcy distribution to $S$ to be an irreversible fait accompli, even though excessive, so that $O C$ will receive only the remaining $\$ 70$ in the estate and suffer from a failure to achieve corrective justice, or whether $T$ will invoke an asserted equitable power ${ }^{52}$ to recover the amount of the $\$ 5$ overpayment to $S$. Judicial opinions appear never to have focused sharply on these two alternatives, so that a definitive answer in terms of existing law cannot be given. If the overpayment recovery were considered and allowed - as I assume it would be - the analytical process would certainly push the court more strongly toward an awareness of the essential similarity of equitable subordination doctrine and fraudulent conveyance law.

2. The Beta Situation: The Tainted Transaction Creates Insolvency. - Suppose that $M$ had owned assets with a fair salable value of $\$ 200$. As before, $S$ and $O C$ each have a legitimate creditor claim against $M$ of $\$ 100$. Each party's Just Share of $M$ upon liquidation is $\$ 100$. Let us refer to this set of facts as the Beta Situation.

If $S$ were to take an Unjust Benefit from $M$ of $\$ 90$, which is less than the amount of his Just Share, $M$ would be rendered insolvent and might go into bankruptcy. As in Alpha, a fraudulent conveyance action by $T$ against $S$ would set matters exactly straight, as would application of the Constructive Distribution Rule. But unlike the result in the Alpha situation where Unjust Benefit exceeded Just Share, the Full Subordination Rule would now lead to a merely corrective result rather than a penalty. Thanks to the pre-unfair-transfer condition of solvency, full

${ }^{52}$ Cf. In re Lilyknit Silk Underwear Co., 73 F.2d 52 (2d Cir. 1934) (without direct authority in Bankruptcy Act, court orders recovery of dividends paid out of the estate pursuant to an order later reversed). See $\$ 57 \mathrm{~g}$, I I U.S.C. $\$ 93(\mathrm{~g})$ (1970). 
subordination and the resulting full satisfaction of $O C$ 's claim does not give him more than his Just Share, with a resulting penalty upon $S$. As for the Offset Rule, it now leads to proper correction rather than undercorrection, for essentially the same reason.

If, however, the Unjust Benefit taken by $S$ had been $\$ 110$, thus exceeding his Just Share, problems of undercorrection reemerge. Fraudulent conveyance law and the Constructive Distribution Rule will again yield a simple corrective result..$^{53}$ The Full Subordination Rule now leads to undercorrection - $O C$ gets only the $\$ 90$ left in the estate - as in Alpha, part $b$. The Offset Rule now also leads to undercorrection, at least if one assumes that $S$ 's legitimate claim cannot be effectively reduced below zero under this rule. $O C$ and $S$ would share the nonaugmented estate of $\$ 90$ on a $100 / 0$ basis; OC gets $\$ 90$, which is less than his Just Share.

It is hoped that the systematic considerations set forth above will lead one to conclude that the Constructive Distribution Rule is theoretically the best of the three interpretations of equitable subordination. Since the Full Subordination Rule can grant a boon rather than impose a punishment - as when the Unjust Benefit is greater than the Just Share and the estate is already insolvent - one cannot justify the Rule on the theory that fraud, whether actual or constructive, should be punished as well as corrected. Furthermore, the variations in outcome depend on mathematical relationships between Unjust Benefit and Just Share that have nothing to do with the legal policies involved. Indeed, from one point of view the relationships are positively counterintuitive: other figures being kept equal, the controlling party will maximize the legally retainable benefits from an unfair transaction by increasing the degree of unfairness. ${ }^{54}$ The Offset

${ }^{53}$ They will always yield a corrective response under the restrictive conditions governing this analysis.

${ }^{54}$ It should be noted that in some situations application of the Full Subordination Rule will lead to the same result as a successful fraudulent conveyance action for reasons other than an accidental equivalence between Unjust Benefit and Just Share. One pattern is that presented when the pre-bankruptcy transfer of an Unjust Benefit to the controlling parties consisted of creating a nominal creditor claim on the part of those persons against the corporation, and the controlling parties have no other, legitimate creditor claims against it. The well known case of Costello v. Fazio, 256 F.2d 903 ( 9 th Cir. 1958) is a beautiful example of this pattern. Two of the partners in a failing business attempted to "withdraw" a substantial portion of their equity investment in the partnership by converting it into demand notes. The partnership was then incorporated, the notes were assumed, and the corporation marched straight into the valley of bankruptcy. 
Rule, while never leading to overcorrection, does frequently lead to undercorrection. Further examples would indicate a relationship that might be intuitively obvious to a mathematician, namely, that in ordinary situations (insolvency even apart from the tainted transaction), the degree of undercorrection is mitigated insofar as (a) the amount of the Unjust Benefit is less than the amount of $S$ 's Just Share and (b) the face amount of $S$ 's legitimate creditor claim is less than the face amount of $O C^{\prime}$ 's creditor claim. In a sense, then, the deviations from simple corrective justice caused by the Offset Rule are arbitrary in a more complex fashion than those caused by the Full Subordination Rule. The Constructive Distribution Rule, however, always results in exactly corrective justice. Therefore, if the Constructive Distribution Rule is the best interpretation, the results of equitable subordination and of fraudulent conveyance law are functionally equivalent.

The notion that equitable subordination may be a substitute for a fraudulent conveyance action is illustrated by almost all of the leading subordination cases. To take an example, the celebrated equitable subordination case, Taylor v. Standard Gas $\mathcal{E}$ Electric Co. (Deep Rock), ${ }^{55}$ involved a complex series of inequitable or highly suspicious actions by Standard, the parent corporation in control of the debtor corporation (Deep Rock). ( I) Standard caused Deep Rock to enter into a lease with another subsidiary which was unfair to Deep Rock. The subsidiary was then required to turn the lease receipts over to Standard. ${ }^{56}$ (2) Standard caused Deep Rock to enter into a management contract with another subsidiary and pay it steep management fees. ${ }^{57}$ (3) Standard charged interest at a high rate on its open account with Deep Rock..$^{58}$ (4) Standard caused Deep Rock to pay it dividends when Deep Rock could hardly afford them. ${ }^{59}$ Given

If the business is regarded as having been one continuing business, and the switch from partnership to corporate form is therefore disregarded, the case presents a rather simple and straightforward example of a fraudulent conveyance: the business, while insolvent, transferred a benefit (the notes) to certain persons without receiving fair consideration. The response under fraudulent conveyance law would be that the trustee would seek to recover the benefit by bringing a suit to void the notes. In the actual case, equitable subordination, as operationalized by the Full Subordination Rule, yielded the same result. The court, in fact, did not even mention that the transaction was a fraudulent conveyance, possibly because it overcautiously thought that the switch from partnership to corporate status created problems under that analysis.

55306 U.S. 307 (1939).

${ }^{56} I d$. at $319-20$.

${ }^{57}$ Id. at $3 \mathrm{II}$.

${ }^{58} I d$. at 320 .

${ }^{59} \mathrm{Id}$. at $3 \mathrm{I} 7$. 
the continuous inadequacy of Deep Rock's capitalization, ${ }^{60}$ and assuming (as the Court undoubtedly did) unfairness in these transactions, all of them were fraudulent conveyances. ${ }^{61}$

Pepper v. Litton ${ }^{62}$ presents a neater example of this substitution. Scheming to defraud the corporation's creditors, a controlling stockholder accumulated large, unpaid salary claims owing to himself. Suing on them, he caused the corporation to confess judgment and used the judgment, as well as other delaying actions, to hinder a major creditor. The corporation's incurrence of the salary claim was, under the circumstances, a fraudulent conveyance. ${ }^{63}$

${ }^{60}$ See id. at 3 10 (from its organization "two jumps ahead of the wolf").

${ }^{61}$ See UFCA $\$ 5$.

The Deep Rock case may also illustrate complementary uses of equitable subordination doctrine. If the Court thought the initial undercapitalization was a sufficient basis for subordination - I doubt that it did - then fraudulent conveyance law could not substitute for equitable subordination since no transfer would be involved. A more convincing and important point is that the subordination of Standard's creditor claims to the claims of Deep Rock's preferred shareholders would not be possible under fraudulent conveyance law. See generally section II.C. infra.

62308 U.S. 295 (1939).

${ }^{63}$ See UFCA $\S \S \mathrm{I}, 7$.

Other important cases also suggest that equitable subordination can substitute for fraudulent conveyance law. In Comstock v. Group of Institutional Investors, 335 U.S. 2 II (I948), the majority affirmed a plan of reorganization which accepted as valid the claim of a parent railroad company against its subsidiary on the basis of the lower court's finding of fair dealing. 335 U.S. at 230. The dissenters, however, pointed to eleven instances of loans by the parent to the subsidiary which were followed within a few days by dividends of similar or slightly smaller amounts from the subsidiary to the parent. Id. at 240 . The dissent argued that compelling the subsidiary to pay dividends while it was debt-heavy and cash-poor was the type of "mismanagement" that should lead to equitable subordination. Id. at 247 . The dissenters were rightly suspicious, though they would have been more persuasive if they had not focused on the dividend payments. If the loans are integrated with the dividends, it is seen that the parent was causing the subsidiary to incur obligations to itself without giving the subsidiary fair consideration, i.e., full equivalent value. To do this when it will leave the subsidiary with inadequate capital in relation to its debts is to cause it to effect a voidable fraudulent conveyance. See UFCA $\S \S 5,7$. The dissent's other bone of contention, that the parent for its sole benefit caused the subsidiary to assume obligations of another subsidiary without consideration and while the subsidiary was on the threshold of reorganization, also involved a fraudulent conveyance, though again this analysis was overlooked.

A fascinating example of the "bootstrapping" fraud, accompanied by an equally fascinating judicial response, is provided by In re Process-Manz Press, Inc., 236 F. Supp. 333 (N.D. Ill. I964), rev'd on jurisdictional grounds, 369 F.2d $5 \mathrm{I}_{3}$ (7th Cir. I966), cert. denied, 389 U.S. 957 (1967). Greatly simplified, the important facts were as follows. The shareholders of Manz sold their stock to Lithographers on an installment basis. Lithographers later found it financially difficult to make payments. An arrangement was worked out whereby Armstrong, a finance com- 


\section{B. Explanation of the Existence of Equitable Subordination Doctrine}

Since equitable subordination is properly viewed largely as a functional substitute for fraudulent conveyance law, which the trustee in bankruptcy is well able to invoke, why did equitable subordination ever come into existence? The answer to this question emerges when one begins lifting the three restrictive conditions that form the context of the Alpha and Beta Situations discussed above. Two of these conditions, which are obviously related, were zero transaction costs and simple transactions.

One set of transaction costs contributing to the early development of equitable subordination may have been no more than speculative. Bankruptcy trustees appear to have believed

pany, obtained a mortgage on the real estate of Manz and a security interest in some of its personal property. Of the loan proceeds given by Armstrong, however, about \$1.5 million actually went to old, selling shareholders of Manz, discharging obligations of Lithographers. At the direction of Armstrong's chief counsel, this aspect of the transaction was dressed up as a redemption of Manz preferred stock held by Lithographers. $236 \mathrm{~F}$. Supp. at 337-39. The $\$ \mathrm{I}, 500,000$ did not really benefit Manz, which therefore did not receive fair consideration for the note and security interests it gave. Armstrong wanted as security, not only the Manz stock which its real borrower, Lithographers, could pledge to it, but also the assets of Manz, for it was only by an interest in the latter that it could hope to come ahead of Manz's creditors. Manz later went into Chapter XI proceedings. Because of Armstrong's knowledge and participation, the referee in bankruptcy, and the district court in affirming, explicitly held the mortgage liens void as violating various fraudulent conveyance rules (Bankruptcy Act $\S 67 \mathrm{~d}(2)$ (b)-(d), II U.S.C. $\S 107$ (d) (2) (b)-(d) (1970)). Id. at 346-47. The transfers were also found voidable as part of a conspiracy to cause an illegal stock redemption - illegal because of Manz's insolvency. Id. at 348 ; see part IV infra.

In addition, the referee and district court invoked equitable subordination doctrine to subordinate the entire claim of Armstrong against Manz, on an alter ego theory. Armstrong was not really a creditor of Manz but a holder, through its loans to Lithographers, of stock in Manz, and should therefore be paid only after the creditors of Manz were satisfied. Id. at 348. Strangely, though the discussions of fraudulent conveyance rules and equitable subordination were only a few paragraphs apart, the district court seems not to have noticed that the claims effectively might have been subordinated under fraudulent conveyance rules by voiding them as obligations fraudulently incurred by Manz, see Bankruptcy Act $\S 67 \mathrm{~d}(2)$ (c), (d), II U.S.C. $\S 107$ (d) (2) (c), (d) (1970), with the result that Armstrong could share in the estate only as holder of Manz stock (which it was). If ever there were a case in which the functional substitutability of fraudulent conveyance law and equitable subordination doctrine could easily be observed, this was it; yet, the court does not observe the parallel.

See also Costello v. Fazio, 256 F.2d 903 (9th Cir. 1958); International Tel. \& Tel. Corp. v. Holton, 247 F.2d 178 (4th Cir. 1957); In re Dean \& Jean Fashions, Inc., 329 F. Supp. 663 (W.D. Okla. 1971). None of the above subordination cases expressly analyzed the relationships between fraudulent conveyance law and equitable subordination. 
that in order to recover fraudulently transferred property from claim-filing creditors of the estate, they could not act within the so-called summary jurisdiction of the bankruptcy court, ${ }^{6+}$ but rather had to initiate more expensive plenary proceedings. Before the Supreme Court's opinion in Katchen v. Landy, ${ }^{65}$ it may not have been clear to courts and litigants that a bankruptcy court without possession of the fraudulently transferred property indeed had summary jurisdiction to seek affirmative relief against a fraudulent transferee who did not affirmatively consent to bankruptcy court jurisdiction but merely presented a claim that could be disallowed or subordinated on grounds of fraud or the like. Invoking a fraudulent conveyance theory would have suggested starting new, and expensive, litigation in another forum. ${ }^{66}$ When the trustee invokes equitable subordination, however, everything relevant thereto emerges safely within the scope of the bankruptcy court's summary jurisdiction, for the trustee is simply objecting to the pro rata allowance of a claim. Before

${ }^{64}$ See generally Treister, Bankruptcy Jurisdiction: Is It Too Summary?, 39 S. CaL. L. Rev. 78 (1966). Treister states that summary jurisdiction is the only kind of jurisdiction that bankruptcy courts have, since plenary suits proceed in a state forum or in a federal district court not sitting in its capacity as bankruptcy court. This is generally true, though it apparently overlooks the possibility of plenary proceedings in the bankruptcy court, see Bankruptcy Act $\$ \$ 60 \mathrm{~b}, 67 \mathrm{e}$, $70 \mathrm{(3)}$, II U.S.C. $\$ \S 96(\mathrm{~b})$, IO7(e), IIO(e)(3) (I970). But see note 65 infra.

${ }^{65} 382$ U.S. 323 (I 966 ).

Under the confusing language of $\$ 67 \mathrm{e}$ of the Bankruptcy Act, a trustee might have brought a fraudulent conveyance action against a transferee or obligee (even if the latter had not presented a claim in the bankruptcy court) in an appropriate state court or in a "court of bankruptcy," but the provision had been interpreted to require the trustee to confine his choice to a state court or a United States district court (rather than the bankruptcy judge as such), unless there was some other ground to litigate the matter in the bankruptcy court. See 2 J. Moore et al., Collier on Bankruptcy $\llbracket 23.15$, at 605, 622-23 (i4th ed. rev. I973). Venue, service of process, pleading, and practice in plenary suits under $\S$ $67 \mathrm{e}$ are discussed in $4 \mathrm{~J}$. Moore ET AL., supra note I, at $\pi \uparrow 67.46,67.47$.

Katchen held that one who filed a claim in the bankruptcy proceeding might be compelled to surrender preferences that under Bankruptcy Act $\$ 57 \mathrm{~g}$ would require disallowance of the claim. In view of $\S 57 \mathrm{~g}$ 's language, the reasoning of the case would extend to cases involving voidable fraudulent transfers. In hindsight, a precursor of Katchen may be seen in a well - known fraudulent conveyance case that interpreted narrowly the rule that a plenary suit was required when the property in question was in the actual possession of a "substantial adverse claimant." See Sampsell v. Imperial Paper Corp., 3 I3 U.S. 2 I5 (I94I).

${ }^{66}$ While proceeding in a district court under the Federal Rules of Civil Procedure is not, given the present Bankruptcy Rules, significantly more burdensome than an adversary proceeding before the bankruptcy judge, the district court proceeding may involve considerably more delay and may, in former times, have involved additional procedural burdens. Notice that a plenary suit is still needed when an insider has caused the corporate debtor to make a fraudulent transfer to a third party and recovery is sought from that party. 
Katchen v. Landy, then, the doctrine may have functioned as a way of avoiding the burdens of the plenary suit which apparently was always called for by fraudulent conveyance theory. ${ }^{67}$

A more likely explanation of equitable subordination appears when one lifts the assumption about simple transactions. In fact, many of the equitable subordination cases-Pepper $v$. Litton $^{68}$ is the classic example - involved an incredibly complex series of controlling party transfers and other transactions. It would be extremely difficult and costly, if not impossible, to attempt to analyze separately each step in the series, to assess all the evidence relating thereto, to make numerous separate findings as to insolvency and fairness of consideration, and to draw conclusions as to the proper amount of recovery at each step under the apparently exacting tests of the UFCA. ${ }^{69}$ Though

${ }^{67}$ Logically, this explanation of equitable subordination really constitutes just a reason for the trustee's avoiding a fraudulent conveyance action seeking affirmative recovery. He could theoretically do this without using equitable subordination doctrine as the avoidance device. For example, he could raise the objection under Bankruptcy Act $\$ 57$ g, I I U.S.C. $\$ 39$ (g) ( I 970), that the insider's claim should be disallowed because he had made a fraudulent transfer. Since in the common, substantively insolvent estate, subordination is practically equivalent to disallowance, this approach would yield the same result as equitable subordination doctrine (applied in light of the Full Subordination Rule), except that it would give the insider an additional, sometimes advantageous, option: that of surrendering the fraudulently transferred property to become able to have his claim allowed. The positive reasons for choosing equitable subordination as the avoidance device are given subsequently in the text.

68 308 U.S. 295 ( I 939 ).

${ }^{69}$ Consider the following:

The basis of [the] claim [subordination of which was in question] was an open account which embraced transactions between Standard and Deep Rock from the latter's organization in I9I9 to the receivership in 1933. The account consists of thousands of items of debit and credit.

.. Many transactions entered in the account were attacked as fraudulent ....

Without going into the minutiae of the transactions between the two companies, enough may be stated to expose the reasons for our decision. . . .

. . . It is impossible to recast Deep Rock's history and experience so as even to approximate what would be its financial condition at this day had it been adequately capitalized and independently managed and had its fiscal affairs been conducted with an eye single to its own interests.

Taylor v. Standard Gas \& Elec. Co., 306 U.S. 307, 3 I I-I 2, 3 I5, 323 (I939) (emphasis supplied).

The vast extent of the railroad business carried on by the Missouri Pacific and the New Orleans during the long past period of alleged mismanagement and the intricate corporate structures of the railroads, inevitably presented most serious problems in the attempts of accountants to picture what their course of operations and financial transactions had been.... There was fundamental controversy as to what inferences should be drawn from the available accounts to establish the true financial condition of the New Orleans at different times.... 
fraudulent conveyance law conceivably could be broadened to sanction a gestalt approach comparable to the step transactions doctrine in tax law, ${ }^{70}$ rather than to require a transaction-bytransaction analysis and legal conclusion in all cases, it has seemed less violent to tradition to invoke a more obviously amorphous doctrine to which the label "equitable" is attached.

The third restrictive condition used in our earlier analysis was that equitable subordination should seek to do corrective justice, eschewing both undercorrection of fraudulent and unfair transfers and punishment of the participants in them. Unlike the other two conditions, which are simplified assumptions about how the world is, this condition is a policy judgment about what the law's goal ought to be. Pressure to give up or deemphasize the goal of precise corrective justice is, of course, generated by the very factual complexity which made the second condition unrealistic. Complexity not only drives courts to devise a doctrine that will avoid the necessity of applying all of the criteria of a fraudulent conveyance to each segment of a complicated series of transactions. It also pressures them to adopt the simple Full Subordination Rule rather than the precisely corrective Constructive Distribution Rule, since the latter obviously requires that a greater number of specific facts be determined.

Nevertheless, a nonpunitive interpretation of equitable subordination - the view that the doctrine ought not to be applied in a way known to be punitive in the particular case - is generally justified, and not a condition that ought to be abandoned. Even if in all cases equitable subordination doctrine could achieve punishment in proportion to some relevant index of guilt, many of the transactions characterized as fraudulent, both for purposes of fraudulent conveyance law and equitable subordination, involve conduct which is not clearly shown in litigation to be willfully wrong or criminal in nature or to betoken moral depravity in any ordinary sense. Though some cases involve intentional wrongs such as deliberate falsification of records ${ }^{71}$ most cases of fraud and mismanagement involve less obvious wrongs and may frequently be proven in court only in terms of mechanical financial tests. For example, the corporation may have paid,

Comstock v. Group of Institutional Investors, 335 U.S. 2 II , 223-24 (I948) (quoting Comstock v. Group of Institutional Investors, I63 F.2d 350, 356 (8th Cir. 1947)).

${ }^{70}$ See, e.g., Mintz \& Plumb, Step Transactions in Corporate Reorganizations, I2 N.Y.U. Inst. ON Fed. TaX. 247 (I954).

${ }^{71}$ Deliberate falsification of records is an intentional wrong that might be subject under ordinary tort principles to punitive damages, see W. Prosser, Handbook OF THE LAW OF TORTS $683-86,735-36$ (4th ed. 1971), and criminal prosecution, see, e.g., I8 U.S.C. $\$ \mathrm{I}_{52}$ (I970). 
while insolvent, what is now found an excessive salary. ${ }^{72}$ Because plaintiffs in civil cases are required to prove their cases by only a preponderance of evidence and because morally opprobrious fraud may be punished through other techniques, ${ }^{73}$ regarding fraudulent conveyance law and equitable subordination as basically corrective rather than punitive seems more reasonable and practical.

Nonetheless, the fairness of requiring a careful and precise examination of evidence and computation of damages in an attempt to do corrective justice must be balanced against the cost of achieving precision and the mildly punitive attitude that the controlling parties should bear the risk of mistakes. ${ }^{74}$ At some point, it becomes obvious that a fraud or mismanagement case is so complex that one is justified in substituting a perception of an entire pattern of conduct for a sequence of focused looks at the elements and the shotgun for the rifle as remedy. ${ }^{75}$ Furthermore, judges naturally feel that in uncertain and complex cases the fraudulent transferee should bear the risks of remedial imprecision. The lure of equitable subordination doctrine may be explained in part by the erroneous but understandable belief of judges that any imprecision in the corrective function of the doctrine typically bears down on and punishes a transferee who was in some sense at fault, as by causing the suspicious series of transactions. ${ }^{76}$

${ }^{72}$ Even a long history of spending as if there were no tomorrow will more readily trigger exasperation and a desire to oust the rascals than a desire to jail them

${ }^{73}$ In addition to punitive damages in tort suits and criminal penalties, see note 7I supra, consider the facts that an actual fraudulent conveyance is an act of bankruptcy, Bankruptcy Act, $\$ 3$ a(I), II U.S.C. $\$ 2$ I (a)(I) (1970), and a reason for denial of the bankrupt's discharge of his debts, Bankruptcy Act, $\S \mathrm{I} 4 \mathrm{C}(4)$, II U.S.C. $\S 32(\mathrm{c})(4)(\mathrm{I} 970)$. Admittedly, the latter effect is of little concern to a bankrupt corporation.

${ }^{74}$ See part III infra.

${ }^{75} \mathrm{~A}$ good example of how equitable subordination steps in when a course of conduct bothers the court, even though one prior, isolated transaction has been corrected by a trustee's action, is given by Bankers Life \& Casualty Co. v. Kirtley, 338 F.2d 1006, I0II (8th Cir. I964).

${ }^{76}$ Moreover, the existence of equitable subordination may be partly explained by less easily defended judicial objectives, such as the desire to overcome technical restraints on fraudulent conveyance actions - for example, the statute of limitations. See, e.g., Comstock v. Group of Institutional Investors, 335 U.S. 21 I , 226 (1948). Bankruptcy Act $\$ 67 \mathrm{~d}(2)$, II U.S.C. $\$$ Io7(d)(2)(1970), makes voidable fraudulent transfers made and obligations incurred within one year before filing of the bankruptcy petition. An action under $\S$ 70e, II U.S.C. $\S$ IIO(e) (I970), based on state fraudulent conveyance law, would be governed by a state statute of limitations. (The UFCA itself contains no limitations period.) In either case, the action might not catch the earlier phases of a long history of abusive parent company dealings with its subsidiary. 


\section{Complementary Uses of Equitable Subordination}

It must be admitted that equitable subordination can be used to achieve results that are foreign to fraudulent conveyance law as conventionally formulated, such as protection of preferred or minority shareholders (who are not creditors within the meaning of the UFCA) and remedying of conduct which defeats the ideal of Nonhindrance but does not involve a transfer. Conduct of a bankrupt corporation caused by controlling parties may violate ideals of Truth, Respect, and Evenhandedness with reference to other equity claimants against the enterprise, even though those claimants cannot invoke the UFCA or similar law because they are not technically creditors. ${ }^{77}$ In truth, there appears to be no good reason why the ideals of Nonhindrance should not be imposed on corporate debtors as duties toward their equity claimants. ${ }^{78}$ In this sense, equitable subordination doctrine may be viewed as a desirable finishing touch to fraudulent conveyance law.

One instance of the application of equitable subordination to a case not involving a transfer is waste of corporate assets by controlling parties. If the waste does not cause some sort of transfer, ${ }^{79}$ such as a salary payment to an idle officer, the situa-

${ }^{77}$ That fraudulent conveyance law has developed in such a limited way is understandable, given its ancient lineage and the relative modernity of the prevalent practice, via the corporate device, of having separate legal entities which can own property and conduct business but which are themselves "owned" by separate persons.

${ }^{78}$ The Deep Rock case involved subordination of parent company "creditor" claims to the claims of preferred shareholders, and those seeking subordination in Comstock, discussed in note 6r supra, merely had a security interest in the debtor corporation's stock. See also Bankers Life \& Cas. Co. v. Kirtley, 338 F.2d I006 (8th Cir. I964) (subordination of dominant stockholders to minority public stockholders).

On the other hand, if fraudulent conveyance law and equitable subordination doctrine were expanded to cover all the myriad ways in which one (controlling) group of equity claimants achieved a non-pro rata distribution from a corporation at the expense of other equity claimants of the same class, they would swallow up a very large part of corporate law. To note this is not to suggest that Deep Rock opened a floodgate that cannot be closed, but to point out that there is an intimate structural and legal relationship between fraud or unfairness which harms creditors and that which harms shareholders. $C f$. Superintendent of Ins. v. Bankers Life \& Cas. Co., 404 U.S. 6 (I97I) (Section ro(b) of the Securities Exchange Act of 1934 applies against deceptive practices even though creditors of the defrauded corporate buyer or seller of securities may be ultimate victims; controlling stockholder's fiduciary obligation extends to creditors as well as stockholders). A full comparison of fraudulent conveyance principles and insiders' fiduciary duties to minority shareholders remains to be made.

${ }^{79}$ Surprisingly, this is rarely the case. Suppose that the corporation's officers were simply lazy and did not work very hard to bring in corporate revenues. As 
tion would not trigger fraudulent conveyance law. Even if applicable, fraudulent conveyance law would often lead to only partial correction since the harm to the corporation from sheer laziness in management, for example, may exceed the entire salaries actually paid to the officers. ${ }^{80}$ For the same reasons of cost reduction and administrative convenience that lead trustees to transform conventional fraudulent conveyance lawsuits into requests that the bankruptcy court grant equitable subordination, the trustee will prefer to invoke the latter doctrine rather than bring a plenary suit for waste. It should be apparent, though, that the simplified remedy of equitable subordination may overshoot or fall short of the mark, depending on the relationship between the amount of the claims asserted in bankruptcy by the controlling parties and the actual amount of harm caused the corporation by their wasteful conduct.

Besides protecting minority shareholders and providing a shotgun approach to wasteful conduct of controlling parties, equitable subordination also appears to go beyond fraudulent conveyance law in the so-called inadequate capitalization cases. Although inadequate capitalization by itself has rarely been a sufficient condition to lead to subordination of the controlling creditor's claim - and some courts have expressly held that it is not sufficient - thin capitalization quite often accompanies real deception. An interesting aspect of the cases involving only inadequate initial capitalization is that they involve no transfer of benefits, except perhaps by analogy to adequate capitalization followed later by an unlawful dividend. ${ }^{81}$ Without a transfer of benefits which could in principle be measured and simply undone,

a result, the corporation becomes insolvent. It could very well be that the conduct of the officers implies that their salaries were excessive, and thus, that they caused the corporation to make transfers of benefits to them that are voidable under UFCA \& 4 .

${ }^{80}$ If this is so, an action for waste would seem to be called for, and, perhaps, on principles similar to those expressed in proximate causation doctrine in ordinary tort law, the officers should be responsible for the entire proximate damage to the corporation. Since the trustee in bankruptcy succeeds to all the causes of action of the bankrupt corporation, he could, if he wished, bring a plenary suit against the officers for waste under state law. However, for the same reasons of cost reduction and administrative convenience that lead trustees to transform conventional fraudulent conveyance lawsuits into claims that equitable subordination should be applied, the trustee will prefer to invoke the latter doctrine rather than bring a plenary suit.

${ }^{81}$ The analogy would be to adequate capitalization followed later on by an unlawful dividend, which would be a violation of the normative ideal of Respect. The analogy is probably not accurate, because the actual presence of the adequate capital during the interim between organization and the dividend later deemed unlawful would probably have helped the corporation to perform better and would thus have saved the creditors some loss. 
choosing the scope of the creditors' remedy for the harm resulting from inadequate capitalization is difficult. The choice is essentially between automatic full subordination of the shareholders' creditor claims, or an attempt to compensate the outside creditors for that portion of their prospective loss in bankruptcy proximately caused by the inadequate capitalization itself. In most cases, realistically attempting the latter task would be too difficult, and the court would therefore be driven to use a blanket subordination of all creditor claims of the relevant controlling parties. In any event, a similar point can be made in the inadequate capital situation as in the case of the pure waste situation: equitable subordination is a functional substitute for, though not an equivalent of, a trustee action to "pierce the corporate veil" under state law. The substitution may not be adequate, since in some cases the outside creditors' harm from inadequate capitalization may not be corrected in full by a mere subordination of the controlling party's claims, and in other cases the response may be essentially punitive.

As suggested, it is unclear that in actual cases equitable subordination ever results merely from inadequate capitalization. ${ }^{82}$ In one view, even the most extreme degree of leverage does not, by itself, cause a debt claim to cease to be a debt claim; the question of fairness really resolves itself into one of full disclosure to outside creditors, with a meaningful opportunity given them to bargain for higher interest payments as compensation

${ }^{82}$ In neither Deep Rock nor Pepper $v$. Litton, nor in any of the cases cited in note $6_{3}$ supra, did inadequate initial capitalization of a controlled subsidiary truly function as a sole and sufficient basis for subordination. There is language suggesting that inadequate initial capitalization was sufficient for subordination in the Holton, Costello, and Dean $\mathcal{E}$ Jean Fashions cases, see note 63 supra, but all of these cases involved an attempt to convert an equity interest into a debt interest in an ongoing business enterprise (thus producing inadequate capitalization): there was objectionable inadequacy of "initial" capital only if one focuses on the new corporate entities in those cases and not on the underlying businesses. Furthermore, some cases explicitly indicate that inadequate capitalization is not a sufficient basis for subordination. E.g., In re Brunner Air Compressor Corp., 287 F. Supp. 256 , 262 (N.D.N.Y. I 968); accord, In re Branding Iron Steak House, BANkr. L. REP. $(\mathrm{CCH}) \Uparrow 65,983$ (9th Cir. May 24, 1976) (mere initial undercapitalization not enough to justify subordinating claims of an officer and director).

On the other hand, an occasional subordination case is difficult to explain as anything but a pure inadequate initial capitalization case. See e.g., Arnold v. Phillips, II7 F.2d 497 (5th Cir.), cert. denied, 3I3 U.S. 583 (I94I). In that case the insider's later purchase at a foreclosure sale under a deed of trust, whereby he acquired, in exchange for his unpaid claims, property of the corporation that was of substantially greater value, could have been characterized as a fraudulent conveyance, but this interpretation is not consonant with the court's language and its remedy (subordination of all initial, but not later, advances, rather than subordination of claims to the extent of the excess value of the foreclosed property). 
for the extreme risk of default. ${ }^{83}$ Inadequate capitalization without any deception might be a basis for subordinating insiders' claims as against tort creditors, on the ground that even apart from statutory requirements (which are almost always met), organizers of the corporation have a duty to provide a "reasonable" amount of net worth for the benefit of persons who might be injured by their tortious activities, but even here the law has displayed very mixed results. ${ }^{84}$ To foreshadow a theme taken up at greater length in part IV ${ }^{85}$ viewing inadequate initial capitalization of a corporation as a wrong to any creditors would appear to invoke affirmative duties to creditors going beyond the simple prohibitions of the ideals of Nonhindrance.

In summary, equitable subordination is not only a functional equivalent of conventional fraudulent conveyance law occasioned by procedural and administrative factors, but also serves the purpose of expanding application of the ideals of Truth, Respect, and possibly Evenhandedness to situations which are not covered by technical fraudulent conveyance law because it is, perhaps arbitrarily, limited in its coverage to debtholder claimants against the debtor and to debtors who make or suffer transfers of benefits.

\section{The Bankruptcy Commission's Proposal: Automatic Rather than Equitable Subordination}

The recommendation of the Commission on the Bankruptcy Laws of the United States ${ }^{86}$ represents a third mode ${ }^{87}$ of implementing the principles of Truth, Respect, and Evenhandedness, that is, a system of preventive rules that penalizes whole categories of transactions without subjecting either each particular transfer or a whole series of them to scrutiny. The Commission's proposal, which appears in two sweeping bankruptcy bills put

${ }^{83}$ See V. Brudney \& M. Chirelstein, Cases and Materials on Corporate Finance 393-95 (1972). Since thin capitalization and the payment of rather ordinary interest rates to outside creditors apparently go together in the undercapitalization cases, it is not surprising that courts have not engaged in the analytical exercise of separating out the legal force, if any, of mere thinness of capitalization from the consequences of thin capitalization in a context suggesting unfairness of one sort or another.

${ }^{84}$ See discussion of Walkovszky v. Carlton at pp. 550-53.

${ }^{85}$ The theme is explored more deeply in that part because there are many more true inadequate capitalization cases decided under the veil-piercing theory.

${ }^{86}$ Report of the Commission on the BankRUptcy Laws of the United States, H.R. Doc. No. 93-I37, Part II, 93d Cong., ist Sess. II5 (1973) [hereinafter cited as Bankruptcy Commission Report].

${ }^{87}$ See p. ${ }_{517}$ supra. 
before Congress ${ }^{88}$ would automatically subordinate any claim of controlling shareholders to those of other creditors. ${ }^{89}$

From the analysis in the previous section, one can conclude that the device of equitable subordination serves a useful function in bankruptcy administration, at least when it is restricted to

${ }^{88}$ H.R. 3I, S. 236, 94th Cong., Ist Sess. (1975) (Bankruptcy Commission's bill); H.R. 32, S. 235, 94th Cong., Ist Sess. (I975) (bankruptcy judges' bill).

${ }^{89}$ Section 4-406. Subordination of Claims.

(a) Subordinated Classes of Claims. The following claims are subordinated in payment to all other nonsubordinated but allowable claims:

(2) any claim, whether secured or unsecured, of any principal officer, director, or affiliate [defined in $\$ \mathrm{I}-\mathrm{IO} 2(4)$ to mean, inter alia, a shareholder controlling 20 per cent or more of the voting securities] of the debtor, or of any member of the immediate family of such officer, director, or affiliate; ....

The Bankruptcy Commission's Report contains no discussion or justification of this proposed change. See Bankruptcy Commission Report, supra note 86, at ir6.

Some case law experimented with automatic subordination. In re V. Locwer's Gambrinus Brewery Co., 167 F.2d 318 (2d Cir. I948) (Frank, J.) held that where the stockholders of a realty company and a brewing company were the same and held stock in the same proportions, the realty company's. loans to the bankrupt brewing company would be subordinated to other claims, on the ground that in such a situation unfairness could easily occur and yet be so easily concealed that no scrutiny by the court would uncover it. In effect, the court in its decision opted for automatic subordination of controlling party claims, relying on the theory that the controlling parties can be presumed to have made fraudulent conveyances to themselves. The theory of automatic subordination was rejected over Judge Frank's dissent in Schwartz v. Mills, 192 F.2d 727 (2d Cir. 1951), where the majority described in Loewer's holding as "not stated as an absolute rule of law," $i d$. at 729. Interestingly, the court mentioned that the petitioner "has given no hint even of fraudulent conveyance, manufactured claim, or mismanagement," id. at 729 ; this is one of the rare suggestions of judicial awareness of the connection between fraudulent conveyance law and equitable subordination. In the wake of Comstock, Judge Frank himself finally acceded - most grudgingly - to the rejection of a rule of automatic subordination of parent company claims in Gannett Co. v. Larry, 22 I F.2d 269 (2d Cir. 1955). There a publishing company, Gannett, acquired Berwin, a financially profitable manufacturer of paper products, and, fearing a newsprint shortage because of the Korean War, converted Berwin's facilities to the production of newsprint. The shortage did not materialize and Berwin, apparently being less efficient than regular newsprint producers, failed. Id. at 269 70, 272. Gannett's claims were subordinated. Judge Frank held that under the circumstances, "proof of fraud or illegality [was] not necessary"; it being sufficient that Gannett "pursued solely its own interests in its management of Berwin," since a newsprint supply was of interest to Gannett whether or not it was financially profitable to Berwin. Id. at 275 . Judge Frank might better have justified his niggardly concession to the Supreme Court precedents by noting that Gannett's wanting to assure a source of supply would hardly make sense except on the assumption that in the expected period of shortage Gannett would not pay Berwin the large scarcity premium for newsprint which its then true market value would warrant - that is, on the assumption that Gannett would cause unfair transfers to itself which might, if accompanied by a threat to solvency or capital adequacy, amount to fraudulent conveyances. As it stands, Judge Frank's opinion makes equitable subordination a substitute for an action based on waste. 
situations where the balance of the equities points to a holistic rather than a particularized analysis of pre-bankruptcy dealings with a corporate bankrupt. The justification for transmuting the doctrine into a rule of automatic subordination of insiders' claims would have to be that the possibilities for insiders to violate the ideals of Nonhindrance by fraudulent and preferential transactions with their corporation are so manifold, so difficult to discover and prove, and so tempting and likely to occur, that it is better not to burden the trustee in bankruptcy, and the outside creditors he represents, with the costs of a doctrine whose uncertainties invite litigation.

On the other hand, a preventive rule that insiders' debt claims are subordinated automatically to those of outsiders may be objectionable because it appears unjust as applied to those insiders who do in fact deal honestly, fairly, and nonpreferentially with their corporations. Indeed, there are compelling arguments which suggest that insiders be allowed to participate in their corporations as creditors on the same basis as outsiders. Controlling insiders, like other investors, should be free to have a portfolio of debt and equity securities so balanced as to meet their risk-return preferences. An investor should not be required to possess, in effect, only the status of a shareholder. The answer to this argument, of course, is that the capital markets of the United States are so richly diverse that a knowledgeable investor can surely create a portfolio consisting of stock in his controlled corporation and debt or equity securities of unrelated entities that will have the same risk-return characteristics as a given portfolio of stock and debt in his controlled corporation.

Another argument urged against an automatic subordination rule is that controlling shareholders are frequently - so it is said - the only persons willing to lend to a small, unknown corporation on "reasonable" terms. It is contended that if the insiders' creditor claim is not respected in bankruptcy, this source of funds may dry up and result in such small businesses' being deprived of the tax benefits of debt financing. ${ }^{90}$

The force of this argument is uncertain because it ultimately rests on unproven empirical assertions concerning the conduct of controlling insiders ${ }^{91}$ and the magnitude of transaction costs involved in assessing and communicating risks of default on

${ }^{90}$ Interest payments by a corporation are generally deductible for federal income tax purposes. I.R.C. $\$$ I63. Dividend payments are normally not. See B. Bittker \& J. Eustice, Federal Income Taxation of Corporations and ShareHOLDERS, $\uparrow 5.03$, at 5-8 (3d ed. I97 I ).

${ }^{91}$ Controlling insiders may continue to lend because they are unaware of automatic subordination or because the corporation has no other creditors to whom they can be subordinated. 
particular loans. If rational and disinterested outside lenders are unwilling to supply corporate "loans" on a given set of interest rates and other terms, the most natural conclusion is that a "loan" of that character would be made only by persons who, by virtue of concurrent stock ownership, could benefit from the inadequacy of the terms, and the "loans" to insiders should thus be treated like equity in distributing the bankrupt estate. True, situations may arise in which insiders (a) really do perceive more accurately that the "true" risk presented by a loan to a corporation on given terms is lower than outsiders recognize, and (b) are unable to articulate and convey the objective bases of their superior judgment to the prospective outside lenders at a reasonable cost. But, in view of the widespread belief in the general efficiency of our capital markets, one might well be agnostic about the notion that such situations are common. In short, objections to the Bankruptcy Commission's proposal based on the just demands of small investors and small businessmen are of doubtful validity.

Nevertheless, the advantages of preventive rules must be viewed in a similarly agnostic fashion. One simply does not know the extent to which insiders who are also creditors abuse their controlling status by dealing dishonestly, unfairly, or preferentially with their corporations, to the detriment of outside creditors. Without such knowledge, the benefits to be expected from the automatic subordination rule are conjectural. This being so, a conservative adherence to equitable subordination is certainly defensible.

Furthermore, the automatic subordination rule imperfectly implements the normative ideals of fraudulent conveyance law. If the proposal were enacted, it would not always lead to an adequate correction of unfair transactions according to these principles. As with the application of equitable subordination doctrine, a controlling insider who does not have a creditor claim against his corporation may have reaped unfair advantage from transactions with his corporation and yet not be affected by application of the automatic subordination rule. However, any detectable inadequacies in the correction of unfair dealings by insiders might still be made up for by the more costly fraudulent conveyance action, ${ }^{92}$ for the recommendation does not preclude a

${ }^{92}$ This relatively heavier procedural burden may be lessened under the Proposed Bankruptcy Act. The Bankruptcy Commission would substantially abolish the distinction between summary and plenary jurisdiction and would make most controversies arising out of a bankruptcy proceeding subject to the jurisdiction of the bankruptcy court. Bankruptcy Commission RePORT, supra note 86, at $30-33$ (§ $2-201$ of proposed act and note thereto). The impact of this change may 
complementary claim on fraudulent conveyance grounds against insiders. ${ }^{93}$ On the other hand, automatic subordination might lead to overcorrection by subordinating an insider's claims in the absence of a violation of the ideals. This result, however, is necessitated by the decision to sacrifice analytical and remedial precision for the certainty and ease of preventive rules.

\section{Fraudulent Conveyances and Piercing the Corporate Veil}

This part will examine a branch of law which mixes consideration of the ideals of Nonhindrance with other policies that warrant comparative analysis in light of those ideals. The doctrines previously discussed were different ways of implementing the same basic ideals, although some expansions of substantive elements were involved. We now turn to a doctrine that appears to go further toward an evolution of the ideals themselves.

As a gloss on state corporation statutes, state and federal courts have developed a sizable body of case law dealing with the attempts of corporate creditors to satisfy their claims out of the personal assets of the corporation's shareholders despite the general rule of limited liability. ${ }^{94}$ Cases of this sort have been referred to by various metaphors, such as "alter ego" or "instrumentality" cases and attempts "to pierce the corporate veil." 95

be diminished somewhat by the new venue rules. Id. at $36-4$ I $(\$ 2-203$ and note thereto).

${ }^{93}$ Provable fraudulent transfers not corrected by the automatic subordination of the insider's claims will have occurred in transactions separate from those that led to creation of the claims. It will therefore be easy to find that the subordination does not preclude a fraudulent conveyance recovery against the insider. If the events leading to the creation of the subordinated claim were not themselves fraudulent, the effect will be that the insider is punished, since he will get no "credit" for the amount returned in the fraudulent conveyance proceeding. But a punitive result is always a possibility under the rule of automatic subordination.

${ }^{94}$ Discussions of the case law are numerous. Among the more interesting treatments, drawn from different time periods, are I. Wormser, DisRegard of the Corporate fiction and Allied Corporation Problems (1927); Berle, The Theory of Enterprise Entity, 47 Colum. L. REv. 343 (1947); Horowitz, Disregarding the Entity of Private Corporations, I4 WASH. L. Rev. 285 (1939); Landers II, supra note 2 ; Landers I, supra note 2 ; Latty, The Corporate Entity as a Solvent of Legal Problems, 34 Мiсн. L. Rev. 597 (1936); Posner, supra note 2; Comment, Alternative Methods of Piercing the Corporate Veil in Contract and Tort Cases, 48 B.U. L. Rev. I23 (1968); Note, Liability of a Corporation for Acts of a Subsidiary or Affiliate, 7I HaRv. L. Rev. I I22 (1958).

${ }^{95}$ See, e.g., Walkovszky v. Carlton, I8 N.Y.2d 4I4, 223 N.E.2d 6, 276 N.Y.S.2d 585 (1966) ("instrumentality"); Goldberg v. Engleberg, 34 Cal. App. 2d 10, 92 P.2d 935 (I939) ("piercing corporate veil"). See also commentary cited in note 94 supra. 
Though behavior which certainly would invoke fraudulent conveyance law often triggers these cases, courts typically ignore the relationships between that body of law and the attempts to pierce. ${ }^{96}$ Moreover, they usually forego any sustained attempt at a remedial theory or even a coherent exposition of the basis of liability, although descriptive summaries are occasionally attempted. ${ }^{97}$ There is also a fair amount of reference in these cases to cases invoking the doctrine of equitable subordination, though careful analysis of the relationships between that doctrine and the instrumentality or alter ego rules is inevitably lacking.

Indeed, cases attempting to pierce the corporate veil are unified more by the remedy sought - subjecting to corporate liabilities the personal assets directly held by shareholders - than by repeated and consistent application of the same criteria for granting the remedy. In particular, the cases revolve not only around

${ }^{96}$ See, e.g., Maryland ex rel. Goralski v. General Stevedoring Co., 2 I3 F. 5 I, 72-79 (D. Md.), aff'd sub nom. Joseph R. Foard Co. v. Maryland ex rel. Goralski, 2 I9 F.827 (4th Cir. I9I4) (subsidiary had small capital stock and parent took profits of business as a management charge that was apparently unfair); Goldberg v. Engelberg, 34 Cal. App. 2d 10, 92 P. 2d 935 (1939) (piercing from behind: creditor of dominant stockholder reaches corporate assets where stockholder, after judgment was rendered against him, had deeded ranch to wife for "love and affection," and wife had later deeded it to corporation); Bartle v. Home Owners Coop., Inc., 309 N.Y. I03, I07-08, I27 N.E. 2d 832, 834 (1955) (dissent) (parent cooperative organized building subsidiary with small capital and caused it to sell homes to parent's members at prices designed to yield no profit to subsidiary; prices presumably unfair to creditors).

An example of the technique of attempting to convert equity to debt in the context of a bootstrap acquisition is given by World Broadcasting System, Inc. v. Bass, I60 Tex. 26I, 328 S.W.2d 863 (I959), where shareholders sold their stock for cash and a $\$ 67,500$ installment note. The note was secured by a mortgage on the corporation's assets and by a promise by the purchaser to dissolve the corporation. The court, not even mentioning fraudulent conveyance law, held that, since the selling stockholders had thus denuded the corporation of its assets, they were personally liable to its creditors to the extent of the funds received. Quite similar factual patterns were presented in Steph v. Branch, discussed in note I4 supra, and in In re Process-Manz Press, Inc., discussed in note 62 supra, but in the former the court explicitly invoked fraudulent conveyance rules and in the latter it partially invoked equitable subordination.

${ }^{97}$ It has been said that in order to make a parent corporation responsible for the acts of a subsidiary corporation under the "instrumentality" rule, there must be, in the absence of express agency, estoppel, or direct tort, three proven elements: (I) control of the subsidiary by the parent; (2) use of control by the parent to commit fraud or a dishonest and unjust act in contravention of legal rights, or to perpetrate a violation of statutory or other positive duty; and (3) proximate causation of plaintiff's injury or loss by the controlling party's breach of duty. See Fisser v. International Bank, 282 F.2d 23I, 238 (2d Cir. 1960); Zaist v. Olson, I54 Conn. 563, 575, 227 A.2d 552, 558 (1967). The tripartite breakdown can be traced at least back to F. Powell, Parent and Subsidiary Corporations 4-6 (I93I). 
violations of the ideals of Nonhindrance but frequently around violations of an alleged policy that corporations should be adequately or reasonably capitalized. ${ }^{98}$ After comparing this policy with the ideals of Nonhindrance, the remedy in the veil-piercing cases (hereinafter, the piercing cases) will be contrasted with those afforded in fraudulent conveyance cases and in equitable subordination cases. Finally, a leading case will be analyzed to show how the policies are mixed and treated in actual litigation.

\section{A. From Nonhindrance to Cooperation: The Relevance of Inadequate Initial Capitalization.}

The ideals of Nonhindrance are clearly involved in piercing cases when the remedy is granted because of an unfair transfer.

${ }^{98}$ Richard Posner's recent article on veil-piercing and equitable subordination seems to me to focus almost exclusively on the problem of adequacy of initial capitalization, and to constitute an elaboration and justification, in terms of microeconomic theory, of what I call the standard initial response to the problem. Posner brings his law-and-economics machinery to bear on the problem and makes an unusually refined and sustained defense of this type of response. See Posner, supra note 2 .

By contrast, the problem of coping with the possibility that the corporation will take steps to increase the riskiness of the loan (by a contract creditor) after the terms have been set, which Posner calls the problem of supervision, are given relatively little attention. These problems of supervision are largely problems that lawyers have traditionally perceived to fall within the province of fraudulent conveyance law.

As the succeeding discussion in the text will make clear, I prefer to analyze the problem of inadequate capitalization more in terms of moral categories than in relation to economic ones. In general, though I find Posner's analysis complementary rather than objectionable, I have two reasons for not adopting his emphasis. First, his elaborate arguments seem to me to be directed towards propositions which, in their essence, have been accepted by judges for decades. Those courts which have dealt with true inadequate initial capitalization situations have generally accepted Posner's basically conservative stance when contract creditors who ought to have been self-informed were involved, see note 82 supra, but have had no problem with giving better treatment to widows of deceased employees and others who might be expected to receive boons, whether in the name of mercy or "excessive transaction costs." See notes 100 \& 104 infra. To be sure, Posner was directing his efforts, not against the case law but against Landers, who had proposed what amounts to an automatic veil-piercing rule as well as an automatic subordination rule.

My second difficulty is that the courts have generally been struggling, not with the relatively academic issue of adequate initial capitalization, but with the widespread phenomenon of selfdealing on the eve of insolvency. This is often so even when courts mention inadequate capitalization as a basis for decision. See notes 63,82 supra. As is often said, a fraudulent conveyance is but the reflex of an insolvent man. It strikes me as insuperably difficult to read and ponder a good sampling of the case law classified under the headings of equitable subordination and veil-piercing, and then to fail to concede that fraudulent transfers and obligations have been the focus of litigation and legal doctrine. I would suggest, therefore, that they also be the focus of commentary. 
Usually, if the outside creditor had knowledge of specific unfair transfers, he would simply bring a fraudulent conveyance action instead of a piercing suit, or would add a fraudulent conveyance count to his complaint in the piercing suit. However, unfair transfers are occasionally involved in piercing suits without being explicitly analyzed as such or related to fraudulent conveyance law. ${ }^{99}$ The reason is similar to that which accounts for some of the equitable subordination cases. The number of unfair transactions with insiders may be large and indefinite, and proof of unfairness and the extent of lack of fair consideration in each instance of a transaction may be difficult or extremely costly.

The degree of involvement of the debtor's moral duties to creditors in the piercing cases is puzzling because of the presence of cases centering upon thinly capitalized corporations. Such cases, which involve a failure to supply adequate capital to a new corporation, are obviously difficult to explain in terms of strict fraudulent conveyance rules, which concern transfers made and obligations incurred. But they are also difficult to explain in relation to the ideals of Nonhindrance.

First, corporations are often attacked as having been inadequately capitalized in situations in which there was no outright deception practiced on creditors and, thus, no violation of the normative ideal of Truth. ${ }^{100}$ Tort creditors frequently will not have relied on the corporation's level of capitalization and thus could not claim to have been deceived in a relevant way. In the absence of affirmatively deceitful representations one is first tempted to remit contract creditors to their own diligence in obtaining and digesting relevant financial information from the corporations with which they deal. However, when the creditors are in a weak bargaining position, for example, small shippers claiming damages for breach of contract against a carrier, or where the complex of interrelated corporations is such that ordinary customers or creditors of one member of the complex might naturally be lulled into thinking that more assets were behind the contract or loan than the balance sheet of that member later shows, the courts have occasionally pierced the veil in favor of those customers or creditors.

${ }^{99}$ See note 96 supra.

${ }^{100}$ This is obviously true in most of the cases in which tort victims seek to pierce the corporate veil. On the other hand, in many cases involving contract creditors dealing with an undercapitalized member of an affiliated group of corporations, or with a corporation whose affairs are merged with those of the dominant stockholder, the courts seem quite influenced by the possibility that the creditor was misled into trusting some person or group other than the corporation per se, or was at least confused. See, e.g., Luckenbach S.S. Co. v. W. R. Grace \& Co., 267 F. 676 (4th Cir. I920) ; Fisser v. International Bank, 282 F.2d 23I, 240 (2d Cir. I960) (dictum). 
This interference with the ostensibly consensual arrangements is based on a perception of unequal bargaining power or a kind of "soft-core" fraud, which is something approaching a violation of the principle of Truth.

Second, the normative ideal of Respect suffers from uncertainty about its relevance and feasibility in the inadequate initial capitalization cases. Such cases differ significantly from gratuitous or unfair transfers from an insolvent but once adequately capitalized business. ${ }^{101}$ In the latter situation, every contract creditor has a fundamental right to expect that such transfers will not be made, and treating this right as a ground rule that need not be expressed undoubtedly cuts down bargaining costs. Moreover, although fraudulent conveyance law forbids gratuitous or unfair transfers by a business debtor when the transferor would be left with an "unreasonably small capital," this rule is probably best thought of as a supplementary expression of the principle of Respect: the flexible concept of unreasonably small capital, which relates to insolvency in its pragmatic meaning, that is, inability to pay creditors, guarantees that mechanical balance-sheet tests of insolvency, which can be arbitrary and misleading, do not vitiate the ideal. Thin initial capitalization is a different matter. It is not so clear that Respect requires that a debtor so capitalize and run his corporate business that it will not raise the risk of failure to outside creditors beyond a certain maximum permissible level. This conclusion is resisted for various reasons. As to contract creditors, fundamental rights and expectations are hard to come by, for the parties can and often do bargain about the allocation of risks and the compensation for bearing them. ${ }^{102}$ And bargaining is generally thought to result in an equal or better allocation of resources than would a flat legal rule - if, indeed, the latter were to have any long-term impact that the parties could not bargain away. ${ }^{103}$ As to unsatisfied tort creditors and the desire to provide for their compensation, alternatives better than veilpiercing may exist. ${ }^{10 \pm}$

${ }^{104}$ See pp. 509-I I supra.

${ }^{102}$ Cf. Fisser v. International Bank, 282 F.2d 23I, 240 (2d Cir. 1960) (undercapitalization per se not sufficient reason for disregarding separate corporate existence; appellants were contract creditors).

${ }^{103}$ See Coase, The Problem of Social Cost, 3 J. Law \& Econ. I ( I960).

${ }^{104}$ See note 123 infra. This is not to deny that, where the need for redress is great, of course, a court may well consider the possibility of better, alternative compensation schemes to be academic, and, on something like a theory of the second best, to permit recovery. See, e.g., Dixie Coal Mining \& Mfg. Co. v. Williams, 22 I Ala. 33I, I28 So. 799 ( I930) (veil of shell corporation pierced for benefit of widow and six dependent children of employee killed in the course of the company's mining operations). The author applauds such decisions. 
Third, the ideal of Evenhandedness could be said to be involved in many inadequate initial capitalization cases in an indirect way. The corporation could be characterized as having been organized so as to maintain a higher probability of satisfying the claims of some creditors - those who investigated the corporation's financial situation before lending and took precautionary measures, such as perfected security interests - than of satisfying the claims of other creditors - tort creditors and contract creditors, such as small trade creditors, who made weaker credit checks. While this state of affairs could realistically be described as operating in a manner "preferential" to some creditors, several points suggest that application of the ideal of Evenhandedness in actual legal proceedings will be somewhat awkward and hesitant. Conventional preferences often involve an intent of the debtor to favor one creditor over others or a conscious effort by one creditor on the eve of insolvency or bankruptcy to grab payment or security before the other creditors do ${ }^{105}$ whereas inadequate capitalization usually results from neither of these motivations. More seriously, there is apparently no accepted theoretical model for determining when a mode of doing business unfairly raises the probability of satisfying one unsecured creditor so high relative to the probability of satisfying another unsecured creditor that some drastic legal remedy such as equitable subordination or piercing the corporate veil ought to be invoked. ${ }^{106}$ Furthermore, the differences in probabilities of satisfaction of sophisticated, bargaining creditors and satisfication of tort or trade creditors could vary greatly, depending on the extent of capital inadequacy and other factors. Thus, it would be extremely difficult to determine what is the minimum "probability difference" that will justify piercing the corporate veil. ${ }^{107}$

${ }^{105}$ See I Bankruptcy Commission Report, supra note 86, at 202-04, 206-10 (1973). It is difficult to understand the special treatment of "floating liens" on personal property except by reference to the usual absence in the immediate prebankruptcy period of preferential intent on the part of the bankrupt and overreaching intent on the part of the creditor.

${ }^{106}$ Not just the decision to capitalize thinly, but other business decisions could cause this divergence of probabilities of satisfaction. For instance, the decision to settle all customer claims quickly and without dispute, rather than to fight and delay them, could result in a relatively small number of such claimants being subjected to the meager payout of straight bankruptcy. Are all such decisions to be a basis for piercing the corporate veil in favor of the relatively disadvantaged creditors? Why restrict relief to the decision to put in lesser capital than that needed to reduce such divergences?

${ }^{107}$ A clear theoretical basis for fleshing out Ballantine's call for a requirement of capital "reasonably adequate for [the corporation's] prospective liabilities," $\mathbf{H}$. Ballantine, Corporations 303 (rev. ed. I946), might be developed along the lines of Learned Hand's famous formula for determining when a defendant in a negligence case acted as a reasonable man. 
In summary, in those piercing cases which are not substitutes for fraudulent conveyance actions but which genuinely turn upon inadequate initial capitalization, the ideals of Truth, Respect,

Hand contended that the amount of care "demanded of a person by an occasion is the resultant of three factors: the likelihood that his conduct will injure others, taken with the seriousness of the injury if it happens, and balanced against the interest which he must sacrifice to avoid the risk." Conway v. O'Brien, III F.2d 6II 6I2 (2d Cir. I940), rev'd on other grounds, 3I2 U.S. 492 (I94I). Judge Hand later restated this thought in algebraic terms: "if the probability be called $\mathrm{P}$; the injury, L; and the burden, B; liability depends upon whether B is less than L multiplied by P: i.e., whether B $<$ PL." United States v. Carroll Towing Co., I59 F.2d I69, I73 (2d Cir. I947). The formula can be criticized in many ways - for example, for not taking into account whether plaintiff could have incurred some burden $\mathrm{B}^{\prime}$ that would have avoided the risk more cheaply than B (the problem of comparative negligence) - but it can serve as a useful starting framework of analysis,

The formula, with the elements construed in marginal terms, can be transferred to the capital adequacy context. B can represent the discounted present value of the cost of an additional increment of equity capital; $\mathrm{L}$, the losses that would be suffered by contract and tort creditors if the corporation were to fail; $\mathrm{P}$, that portion of the probability of failure that would be eliminated by supplying the additional increment of equity capital to the corporation; and PL would be discounted to present value. Whether the veil would be pierced would depend on whether $\mathrm{B}<\mathrm{PL}$. To give corporations incentives to obey the rule, the remedy upon successful piercing would be corporate liability for L. Liability merely for B the cost that the corporation and its stockholders "should have incurred" but didn't - would be inadequate because it would give stockholders an incentive to gamble on the possibility that no liability would ever materialize.

An argument can be made that in certain contexts imposition of veil-piercing liability is pointless. Consider Lender, a rational contract creditor who actually bargains with the corporation. B is less than PL, and Lender's own cost of eliminating the risk PL is greater than PL. To take figures, $\mathrm{B}$ is $\$ 75$ and PL is $\$ 100$. Lender will be willing to pay the corporation or its stockholders any amount short of $\$ 100$, e.g., by charging a lower interest rate, to have them maintain, supply, or obtain at cost B the incremental capital necessary to eliminate the incremental risk. The promise thus paid for might be embodied in loan agreement covenants relating to dividends, financial ratios, the nature of permitted other liabilities, and the like. In sum, failure of the legal system to impose liability on the stockholders for failure to supply the increment of equity capital need not mean that it will not be supplied. See Coase, supra note 103. Commentators have this insight in mind when they say that, in the absence of fraud (deception), the corporate veil should not be pierced on behalf of contract creditors merely because of inadequate capital.

When information and transaction costs make the bargaining strategy unfeasible, then the legal system might prudently impose liability on the corporate shareholders if it is determined that they, more cheaply than the affected creditors, can avoid the incremental risk PL, and if various other guidelines are met. See G. Calabresi, The Costs of Accidents 135-75 (1970). Such perceptions may be behind the cases which allow piercing in favor of tort creditors, trade creditors, and creditors who became such as consumers whose contracts were breached.

An analytically rigorous approach to the problem need not be justified on the ground that it would lead to precise, objective, and actually usable tests of capital adequacy - it probably would not - but may be justified as a tool for encouraging systematic consideration by judges of all relevant considerations and their 
and Evenhandedness, or the more general ideal of Nonhindrance, are often implicated weakly or not at all. Moreover, when implicated they may nevertheless be stifled by the apparent unavailability of a satisfactory and practically feasible rule of implementation. Thus, some of the piercing cases can be interpreted as expanding the ideals of Nonhindrance to a new ideal of affirmative support of creditors' interests through the requirement of an adequate capital structure. Put another way, the thin capitalization cases have experimented with the notion of placing upon business creditors an affirmative duty of cooperation with creditors. As the ambivalence and conflict in the case law suggest, the experiment is certainly not completed.

\section{B. Comparison of Remedies}

The piercing cases appear to employ a shotgun remedy, that is, a remedy less precisely responsive than those invoked in fraudulent conveyance cases, but one more biased toward a punitive result than those invoked by the doctrine of equitable subordination. When not ignoring the question of the scope of the relief completely, courts in piercing cases often assume either that the proper remedy is simply the complete revocation of limited liability. One obvious alternative, where state decisional law recognizes the inadequate capitalization theory ${ }^{108}$ is that the recovery be limited to the amount of the inadequacy of the capitalization. But affirmatively responding to a plaintiff's requests to pierce the veil in either of these ways may fail to compensate completely outside creditors for harm wrongfully caused them if the personal assets of the defendants are insufficient to fill the need. Of course, this possibility is also present in a fraudulent conveyance action. On the other hand, if the personal assets of the defendants exceed either the amount of funds improperly transferred to them from the corporation or the size of the inadequacy of the corporation's capitalization, piercing the veil and imposing liability to the full

interrelationships. Analytical schemes, even if no better than common sense and experience for understanding and predicting empirical realities, often may serve the insurance function of preventing loss of perspective.

${ }^{108}$ Unlike the New York courts, the California courts have emphasized the importance of inadequate capitalization. See e.g., Automotriz del Golfo de California S.A. de C.V. v. Resnick, 47 Cal.2d 792, 306 P.2d I (1957) ; Minton v. Cavaney, 56 Cal. 2 d 549, 364 P.2d 473, I5 Cal. Rptr. 64I (I96I). These cases relied heavily on Ballantine's rather optimistic reading of prior cases: "It is coming to be recognized as the policy of the law that shareholders should in good faith put at the risk of the business unincumbered capital reasonably adequate for its prospective liabilities. If the capital is illusory or trifling compared with the business to be done and the risks of loss, this is a ground for denying the separate entity privilege." H. Ballantine, supra note I07, at 303 . 
extent of their personal assets will overcompensate the creditors for the harm traceable to the defendants' provable or wrongful acts. This result has the effect of penalizing the defendants. ${ }^{109}$

A few examples may show how this punitive bias differs from the remedial imprecision of equitable subordination doctrine. Assume that $M$ corporation has assets of $\$ 100$ and an outside creditor claim of $\$ \mathrm{I}_{5} \mathrm{O}$. The controlling shareholder is chargeable with some acts or omissions that, properly conceptualized, will trigger the doctrine of equitable subordination as well as that of piercing the corporate veil. Assume first that the controlling shareholder has no legitimate creditor claim against $M$, but owns nonexempt personal assets worth $\$ 50$. If $M$ is placed into straight bankruptcy and the trustee in bankruptcy raises no objections, the outside creditor receives $\$ 100$, which is all of the assets. Even if the trustee could successfully invoke equitable subordination and the interpretation of that doctrine as calling regularly for full subordination of the total creditor claims of the controlling party, he would not improve the proceeds available for the outside creditor. On the other hand, if $M$ had not gone into bankruptcy and the outside creditor simply sued $M$, the outside creditor would also receive $\$$ roo. But if he were to pierce the corporate veil successfully, he would reap an additional $\$ 50$ satisfaction of his claim. The extra $\$ 50$ recovery might conceivably put him in a position which matched the result that would have occurred had the controlling shareholder not engaged in the wrongful conduct, though his position might just as well be better or worse than the result. In any event, he fares better than he would if only equitable subordination were invoked on his behalf.

If the controlling shareholder's posture is reversed - if he is assumed to be asset-poor but possessed of a large legitimate creditor claim against his corporation - the result for the outside creditor under the two doctrines is not the opposite of that described in the preceding paragraph. Assume, for instance, that the shareholder in the above example had a legitimate creditor claim against the corporation of $\$ 50$ but no (other) nonexempt personal assets. If $M$ went into bankruptcy and the trustee did not object to the shareholder's creditor claim, the outside creditor

${ }^{109} \mathrm{~A}$ better remedy would be recovery of the amount of harm proximately caused to outside creditors by the relevant misbehavior of the controlling shareholder, whether it was failure to capitalize adequately, wasteful management, or self-dealing and confusion of roles. To be sure, the notion of proximate causation is itself perplexing and largely functional in its orientation, see Calabresi, Concerning Cause and the Law of Torts: An Essay for Harry Kalven, Jr., 43 U. CHI. L. Rev. 69 (1975), but it certainly suggests more accurately the remedial path to be taken in piercing cases than do the other alternatives. 
would receive $150 / 200$ of the assets, or $\$ 75$. If equitable subordination were successfully invoked, he would receive $\$$ Ioo.

In contrast to the role of equitable subordination in the example discussed in the previous paragraph, that doctrine now does better his recovery. Yet it does not follow that the doctrine of piercing the corporate veil will now yield a worse recovery. Without the doctrine, and absent a bankruptcy, the outside creditor's recovery in a suit against $M$ will depend on a number of factors: if the outside creditor wins the "race of diligence" under state law concerning collection remedies, as by being the first to get a judgment or execution lien on $M$ 's property, then the outside creditor will recover $\$ 100$; if the shareholder qua creditor wins the race, however, the outside creditor will recover only $\$ 5^{\circ}$; if there is no race and an assignment for the benefit of creditors is made, both may share pro rata, so that the outside creditor receives $\$ 75$. If, however, the outside creditor sues $M$ and also successfully pierces the corporate veil, he will have access to the shareholder's personal assets. By hypothesis, the latter's only asset is his claim against $M$. If, as may often be the case, that claim is not exempt from creditors' process (at least in a piercing case), then the outside creditor will get the benefit of the shareholder's claim, and thus recover $\$ 100$, the full amount of the assets of the corporation.

Assuming, then, that the outside creditor who pierces the corporate veil can obtain not only the shareholder's ordinary personal assets but also any creditor claim of the shareholder against the corporation, the doctrine of piercing the corporate veil will never yield a result less favorable to the creditor than equitable subordination and may often yield a more favorable one. From the debtor's standpoint, of the two shotgun approaches to remedying the debtor's violation of his moral duties to creditors, piercing the corporate veil is more likely to yield a punitive result. ${ }^{110}$

One further point concerns the availability rather than the nature of the piercing remedy. It is not likely that a trustee in bankruptcy could invoke the doctrine of piercing the corporate veil for the benefit of the unsecured creditors of the bankrupt estate of the corporation. The trustee's avoiding-powers under section $700,{ }^{111}$ which, roughly speaking, incorporates the state law rights of defrauded actual creditors of the bankrupt estate, depend on there being a fraudulent or voidable transfer. The trustee would need evidence of an unfair transfer and of the presence of a defrauded actual creditor before trying to pierce the corporate veil

${ }^{110}$ This statement does not, of course, imply that punitive results are more or less frequent than undercorrective ones. The actual frequency is an empirical question.

${ }^{111}$ II U.S.C. $\$$ IIo(e) (1970). 
under section 7oe; given such evidence, he might just as well bring a fraudulent conveyance action. Assuming the shareholders have not filed claims in the bankruptcy proceeding, either type of action would necessitate a plenary suit. He might prefer a piercing suit in order to impose a punitive recovery on the controlling party, but then he would run up against the common understanding that section $70 \mathrm{e}$ is available for undoing fraudulent transfers, and nothing more. Other avoiding-powers - the trustee's powers to undo preferences, ${ }^{112}$ certain judicial liens, ${ }^{113}$ certain statutory liens, ${ }^{114}$ and fraudulent conveyances, ${ }^{115}$ - also depend on the presence of a transfer, and his possession of the rights of certain hypothetical creditors under section $70 \mathrm{c},{ }^{116}$ though less clear in this respect generally will avail only to undo transfers. ${ }^{117}$ Thus, the trustee is practically remitted to a variety of remedies (including fraudulent conveyance suits and equitable subordination) in the case of unfair transfers, and to equitable subordination in inadequate capitalization cases, but will rarely, if ever, invoke the piercing doctrine. ${ }^{118}$

\section{An Illustration}

A brief discussion of one of the better known piercing cases may illustrate the difficulties perceived by courts that think they are being asked to go beyond Nonhindrance to imposing on debtors an affirmative duty of cooperation with their creditors. In Walkovszky v. Carlton, ${ }^{119}$ a seriously injured tort victim of the employee of a two-cab corporation carrying only the minimum amount of automobile liability insurance attempted to have liability imposed on nine affiliated two-cab corporations and on their

${ }^{112}$ Bankruptcy Act $\$ 60$, I I U.S.C. \$ 96 ( 1970 ).

${ }^{113}$ Bankruptcy Act $\$ 67$ a, I I U.S.C. \$ Io7(a) (I970).

${ }^{114}$ Bankruptcy Act $\$ 67$ c, II U.S.C. \$ 107 (c) (1970).

${ }^{115}$ Bankruptcy Act $\$ 67$ d, II U.S.C. \& 107 (d) (1970).

${ }^{116}$ Bankruptcy Act \& 70c, II U.S.C. \& I Io(c) (1970).

${ }^{117}$ See 4A J. MOORE ET AL., supra note $34, \pi \| 70.55-70.62 \mathrm{~A}$ (specific types of transactions and interests attackable by trustee under $\S 70 \mathrm{c}$ ).

${ }^{118}$ I have been unable to locate a case in which a trustee in bankruptcy successfully sought to pierce the veil of the bankrupt corporation solely because of inadequate initial capitalization. In one case, the court did allow the trustee to proceed under $\S 70 \mathrm{C}$ on a veil-piercing claim, but the facts show that the gist of the offense was an unfair transfer: the trustee alleged that the shareholders deposited corporation funds into their personal bank accounts. Long v. McGlon, 263 F. Supp. 96 (D.S.C. 1967). The Long decision was, in my view, unwise, since it leads unnecessarily to substitution of an imprecise, punitively oriented remedy for the more rational one suggested by a fraudulent conveyance analysis. But see Landers I, supra note 2, at 606-I6, where an extended plea for giving trustees the right to pierce veils is made. Landers' analysis differs from mine in that he does not take fraudulent conveyance law as the basis for understanding the other doctrines discussed in this article.

${ }^{119}$ I8 N.Y.2d 4I4, 223 N.E.2d 6, 276 N.Y.S.2d 585 (I966). 
common owner, Carlton. The victim had alleged that Carlton had systematically "milked" and "siphoned off" the profits of the corporation precisely for the purpose of minimizing the assets of the business that would be exposed to tort claims. The New York Court of Appeals appeared to rule that Walkovszky could succeed only on a "fraud" or an "agency" theory, neither of which he had alleged with sufficient particularity. The apparent negative implication was that a tort creditor in New York cannot pierce the corporate veil solely on grounds of inadequate capitalization.

Since the court disposed of the alleged "milking" in a footnote - without evident awareness of the relevance of fraudulent conveyance rules to the allegation - on the questionable grounds that it was premature and unspecific, ${ }^{120}$ it is not clear just what Walkovszky could have alleged in particular to invoke the socalled fraud theory of piercing. ${ }^{121}$ Inadequate capitalization alone generally does not fall under the rubric of actual or constructive fraud. Moreover, violations of the principles of Truth or Respect are difficult to maintain in connection with inadequate initial capitalization. ${ }^{122}$ Though later withdrawals of profit might be argued to violate the principle of Respect, the court's footnote on the milking claim seems to reject this argument, at least as applied to tort victims who were not such on the dates of withdrawal.

One might be tempted to conclude, then, that the court's opinion amounts to a rejection of the piercing lawsuit in New York, leaving unfair transfers for fraudulent conveyance actions and inadequate capitalization for redress by the legislature, if at all. ${ }^{123}$

${ }^{120}$ Id. at $42 \mathrm{I}$ n.3, 276 N.Y.S.2d at 59I n.3, 223 N.E.2d at io n.3. The charge was thought premature because plaintiff was not yet a judgment creditor of the corporation. If he should become such, asserted the court, he might then sue under the dividend-restriction and similar rules of the business corporation statute. The court overlooked the possibility of suit under New York's version of the UFCA, it having been held long before that a prior judgment is not a procedural prerequisite to suit under that statute. American Surety Co. v. Connor, 25 I N.Y. I, r66 N.E. 783 (1929). (This has also been the consistent interpretation in other states of the UFCA. Note, Fraudulent Conveyances-Necessity of Judgment to Set Aside, i I Mont. L. Rev. 60 (I950) ; see 32 Mich. L. Rev. 705 (I934). Furthermore, New York fraudulent conveyance law has been applied to remedy milking and diversion of corporate assets, even where one of the devices was payment of dividends. United States v. 58th Street Plaza Theatre, Inc., 287 F. Supp. 475, 498 (S.D.N.Y. I 968 ).

${ }^{121}$ In fact, newly added allegations in Walkovszky's amended complaint were later held to state a cause of action, but on the theory that the individual defendants were really conducting business in their individual capacities - a theory which corresponds to the agency or instrumentality theory discussed in the text. Walkovszky v. Carlton, 29 A.D.2d 763, 287 N.Y.S.2d 546 (r968), aff'd, 23 N.Y.2d 7 I4, 244 N.E.2d 55, 296 N.Y.S.2d 362 (i 968 ).

122 See pp. 543-44 supra.

${ }^{123}$ If the legislature felt that tort victims needed greater protection against the 
Such a conclusion would be unjustified, however, because of the curious permission of the court to invoke an "agency theory," that is, to attempt to prove that the corporation was merely an agent or "instrumentality" of the individual shareholder in the latter's carrying out of what was in reality his own business. ${ }^{124}$ The function of the theory in practice is that of loosening up the level of proof and the atomistic nature of the analyses required in a fraudulent conveyance action explicitly denominated as such. Instead of focusing sharply on each dealing of the defendant corporation with its controlling shareholders and confronting di-

vagaries of limited liability, it might require higher initial legal capital requirements for corporations and might impose capital maintenance rules as well. Alternatively, it might mandate the carrying of greater amounts of liability insurance than are presently required. Since either alternative, if imposed in the form of a universal requirement, might entail provision of excessive tort victim security in some lines of corporate business and inadequate provision in others, the requirements might have to be varied for types of business. To avoid the regulatory burden and probable clumsiness of such a scheme, a third alternative that the federal government might mandate would be requiring that contract creditors, including secured creditors, be automatically subordinated in insolvency proceedings to all tort creditors. Given such an absolute rule of subordination, the burden of prodding debtors into securing "adequate" capital or insurance to take care of tort victims would be shifted to those contract creditors, for example, outside lending institutions, who are in a strong bargaining position vis-a-vis the debtor, and the debtor and his creditors could arrange whatever amount of protection against tort victims was judged adequate for them. One suspects that such a rule, since it would create an incentive not only for controlling shareholders (who are typically small businessmen willing to take high risks) but also for powerful and conservative outside parties, would have more impact on corporate practices than even an activist expansion of the doctrine of piercing the corporate veil. Finally, a fourth alternative might be to provide for tort victims in some way other than by increasing the likelihood of there being a person sufficiently solvent to make a defendant in a tort action. First-party compensation schemes such as no-fault insurance are an obvious example. If one focuses not on "tort creditors" generally, but on types of accidental injury problems - for example, the problem of automobile accidents a scheme to lower the high transaction costs and spotty results associated with the fault system may well seem the preferable alternative. Thus, New York's enactment of a no-fault insurance law, N.Y. INs. LAw \$\$ 670-677 (Consol. 1975), constitutes, among many other things, a response to the problem of the two-cab corporation - a response which may turn out to be better than reversal of the decision in Walkovszky.

These remarks are not intended to pronounce definitively upon the substantive merits of the various alternatives to piercing the corporate veil, nor to imply that veil piercing for tort creditors may not be the ideal solution in a given context, under some theory of the second best. The point is that the presence and prima facie attractiveness of the alternatives make some courts unsure of piercing the veil in simple inadequate capitalization cases, even when the beneficiary would be a tort victim.

${ }^{124}$ The permission derives perhaps from Justice Cardozo's attempt in Berkey v. Third Avenue Ry., 244 N.Y. 84 , I55 N.E. 58 (I926) to substitute this mechanistic and opaque theory of liability for what he referred to as the "mists of metaphor." See id. at 94, I55 N.E. at 6r. 
rectly the doctrinal arguments for and against making inadequate capitalization per se a basis for calling off limited liability, the court may find that random instances of self-dealing and mismanagement, in the context of the shareholder's failure to keep corporate books and observe corporate formalities, his or its mingling of corporate and personal (or parent company) assets, and various other utterances and acts which suggest too weak a faith in the reality of the corporate fiction, ${ }^{125}$ is sufficient to make the shareholder unlimitedly liable. All of the latter kinds of "indicia" of agency - the inattention to formalities and the mingling of affairs and assets - are, upon analysis, singularly lacking in direct relevance to the question of the existence, and the amount, of harm caused the outside creditor by the misbehavior of the controlling shareholder. Yet these indicia do at least suggest that fraudulent transfers may have taken place, or that creditors justifiably relied on the creditworthiness of the dominant stockholder or an affiliated corporation, and when sufficiently suffused with intimations and evidence of some actual self-dealing, may create the appearance of a justification for going beyond the limits imposed by doctrine which would require atomistic analysis and a precise remedy.

In summary, the agency theory enunciated in piercing cases serves a practical function similar to that of equitable subordination doctrine, in that both avoid the perceived restraints of fraudulent conveyance law. Understandably, then, the piercing cases suppress mention of that body of law. ${ }^{126}$

${ }^{125}$ See Douglas \& Shanks, Insulation from Liability through Subsidiary Corporations, 39 YALE L.J. I93 (I929); H. Ballantine, supra note IO7, §§ I23, I37, at 294-95, 3 I4-I5.

${ }^{126}$ It should also be mentioned that the technique of doctrinal suppression can be invoked not only to hurt but to help controlling shareholders, when the court feels for whatever reasons that the shareholders should be helped but might be unduly disadvantaged by an analysis in conventional fraudulent conveyance terms. A nice example is given by one of the major New York cases dealing with the attempt of contract creditors of a subsidiary corporation to pierce the corporate veils and obtain access to the assets of the parent corporation. In Bartle v. Home Owners Cooperative Inc., 309 N.Y. I03, I27 N.E. 2 d 832 (I955) the creditors of the subsidiary corporation, a company in the business of building homes that were to be sold to the parent company's shareholders (who were mostly veterans), claimed that the parent corporation had dominated the subsidiary and had run it not in the best interest of the subsidiary itself but for the interest of the parent and its shareholders. In an opinion that is far from satisfactory in its explanation or motivations, the court rejected this claim, which was a standard way of expressing the agency theory. Most interestingly, it completely brushed over the fact that plaintiffs had alleged that the subsidiary had sold its homes at cost to the veterans, 309 N.Y. at I07, I27 N.E. 2 d at 834 (Van Voorhis, J., dissenting) and thus ignored the very real possibilities that a fraudulent convevance action could be brought to set aside these sales, or to recover the excess of market value 


\section{Fraudulent Conveyances and Dividend Restrictions}

The moral duties of the business debtor are also expressed in provisions of business corporation laws which restrict a corporation's ability to pay dividends or to make other kinds of distributions to its shareholders. While perhaps most corporate lawyers perceive a relationship between these restrictions and general fraudulent conveyance law principles,${ }^{127}$ there has been no close analysis of how this relationship may weaken the protection afforded by fraudulent conveyance law. The topic bears some discussion, not only because corporate distributions are of great economic significance, but also because these particular restraints raise the interesting general problem of the role of bright lines in corporate management.

Under the Model Business Corporation Act (MBCA), ${ }^{128}$ as well as the actual laws of many states, ${ }^{129}$ a corporate debtor may not make a transfer in the form of a distribution to shareholders - whether the distribution be a technical dividend, ${ }^{130}$ a distribution out of capital surplus, ${ }^{131}$ a share repurchase,${ }^{132}$ or a redemption ${ }^{133}$ - if, just after the distribution, the corporation would be insolvent in the traditional equity sense of being unable to meet its debts as they become due. ${ }^{134}$ And, of course, a corporation in actual dissolution must pay its creditors before distributing anything to shareholders. ${ }^{135}$ The existence of these overarching and not easily manipulable ${ }^{136}$ restraints on corporate distributions is not

over cost from the veterans, or to recover the excess amount from the parent corporation on the theory that it, as controlling party, was the fraudulent transferor or at least an aider and abettor. Had the court recognized these possibilities, it might have been forced to acknowledge that the case before it was in substance one seeking to recover from the parent as a fraudulent transferor and, therefore, the fact that the homes were to be sold at cost to the veterans was crucial.

${ }^{127}$ See, e.g., W. Cary, Cases and Materials on Corporations i489-90 (4th ed. unabr. I969) (fraudulent conveyance rules are noted as "hav[ing] some bearing upon the avoidance of dividend payments," but are not explicitly compared and contrasted with statutory dividend restrictions).

${ }^{128}$ ABA-ALI Model Bus. Corp. Acr $\$ \S 45,46(\mathrm{a}), 6,66$ (I969) [hereinafter cited as MBCA].

${ }^{129}$ E.g., N.Y. Bus Corp. Law $\$ \S 510(a), 513$ (McKinney 1963 \& Supp. 1976); Cal. Corp. Code $\S$ i50I, (West r976 Supp.) (effective Jan. I, I977).

${ }^{130}$ See MBCA $\$ 45$.

${ }^{131}$ See MBCA $\$ 46(\mathrm{a})$.

${ }^{132}$ See MBCA $\S 6$.

${ }^{133}$ See MBCA $\$ 66$.

${ }^{134}$ See MBCA $\$ 2(\mathrm{n})$.

135 See MBCA $\$ \$ 87(\mathrm{~b}), 98$.

136 There is no statutory procedure for shareholder action to avoid the insolvency test, as there is in the case of the prohibitions against dividends out of capital surplus or legal capital. 
surprising, for they are a straightforward expression of fraudulent conveyance principles. Under the general fraudulent conveyance principle of Respect for creditors, a debtor may not make a gratuitous or unfair transfer if, just after the transfer, he would be insolvent ${ }^{137}$ in a modified balance sheet sense. ${ }^{138}$ The specific restraints on corporate distributions simply remove all doubts as to whether a distribution to shareholders is a "transfer without fair consideration" within the meaning of general fraudulent conveyance law.

However, the UFCA, as well as the Bankruptcy Act, go a significant step further in the protection they would give the creditors of business debtors. UFCA section 5 declares fraudulent any gratuitous or unfair transfer by a debtor in business if, after the transfer, the property remaining in the debtor's hands is "an unreasonably small capital." ${ }^{139}$ The debtor's post-transfer situation must be such that not only do his assets exceed his liabilities, but the amount of the excess - the debtor's net worth, or, in the loose usage of the statute, ${ }^{140}$ his "capital" - must not fall below some reasonable, minimum amount. What constitutes an adequate or reasonable amount of capital, either in general or for particular businesses, is not specified in the statute. Though one can hardly extract specific rules of thumb from the relevant case law, ${ }^{1+1}$ one can at least conclude that the concept of capital is a flexible notion derived from all relevant facts and circumstances in a particular case. The thrust of the notion is a realistic and purposive one: the court must do its best to determine a level of capital which would provide a reasonable minimum level of protection against future decreases in the value of the debtor's assets and its subsequent inability to meet obligations to creditors. Obviously, creditor protection against adverse developments is a matter of degree. While the theory of assessing and measuring the amount of protection provided by given capital levels could perhaps be elaborated and specified by management consultants or economists, the courts in practice must make very rough estimates of the degree of protection afforded to creditors in a particular case. Moreover, the

${ }^{137}$ See UFCA \$ 4 .

${ }^{138}$ See UFCA $\$ 2$.

${ }^{139}$ See also Bankruptcy Act $\S 67 \mathrm{~d}(2)(\mathrm{b})$, I I U.S.C. $\S \operatorname{10}$ (a)(2)(b) (1970), which, unlike UFCA $\S 5$, also covers obligations incurred.

${ }^{140}$ Neither the UFCA nor the Bankruptcy Act define what they mean by "capital" as it appears in the phrase "unreasonably small capital," but common sense suggests that it must mean something like "capital" as the phrase is used in discussions of commercial bank capital adequacy or of reasonable capital in veilpiercing cases. In other words, it has to do with net worth, not just legal capital.

${ }^{141}$ See cases cited in 4 J. Moore ET. AL., supra note I, $\int 67.35$, at 525 n. 8. 
particular degree of protection legally required is a normative stipulation rather than an economic matter.

General business corporation statutes usually contain a number of restraints on distributions that are apparently based on the general notion that a business debtor ought to keep a minimal capital cushion in the business to protect its creditors. Under MBCA section 45(a), for example, dividends may only be paid out of "unreserved or unrestricted earned surplus," or put negatively, not out of legal capital ${ }^{1+2}$ and capital surplus. ${ }^{1+3}$ Nevertheless, one quickly discovers that the restraints are virtually meaningless, for two major reasons: first, because they can be avoided if proper statutory procedures are followed; second, because they are founded on formalistic accounting conventions rather than the UFCA's equity-oriented, purposive concept of capital, which is much more relevant to the question of risk actually posed to creditors.

For instance, the corporate debtor without any earned surplus may, under MBCA section 46, avoid the restriction by making an ongoing "distribution" to shareholders out of capital surplus, ${ }^{144}$ provided that either the articles of incorporation so provide or the shareholders vote to approve the distribution. ${ }^{14 \pi}$ Furthermore, if there is neither earned surplus nor capital surplus, the corporation may be able to invoke MBCA section 69 and obtain a shareholder vote to reduce its stated (legal) capital, thus generating an instant capital surplus from which distribution to shareholders can then be made pursuant to section $46 .^{1+6}$ Moreover, if the corporation had been prudent enough to incorporate in Delaware, it would be able, in effect, to pay dividends out of stated capital without any shareholder vote, if it could meet the requirements of the "nimble dividend" rule. ${ }^{1+7}$ In any event, even an effective prohibition against dividends out of legal capital provides only formalistic protection, since a corporation may be formed with either no minimum

${ }^{142}$ See MBCA $\$ 2(j)$ (definition of "stated capital").

${ }^{143}$ See MBCA $\$ 2(l)$, (m) (definitions of "earned surplus" and "capital surplus").

${ }^{144}$ See MBCA \& $46(\mathrm{e})$.

${ }^{145}$ See MBCA $\$ 46(\mathrm{~b})$.

${ }^{146}$ To be sure, dividends out of reduction surplus can be partially defended on the ground that the roting requirement will slow things down and give some contract creditors a chance to adjust or to take protective measures, e.g., refusing to make further shipments unless paid for on delivery. Also, prudent institutional lenders will have already bargained for a limit on dividends except under conditions acceptable to them.

${ }^{147}$ Under that rule, if the corporation has net positive earnings for the current and immediately preceeding year taken together, it may pay dividends to that extent, even if it has no capital surplus and has inherited an overall earned surplus deficit which the current earnings have not eliminated. 
capital, ${ }^{148}$ or only a trivial amount, ${ }^{149}$ and is not required to increase this amount as the business grows. Furthermore, in some states in which ordinary dividends may be paid out of surplus, the amounts shown as surplus may include revaluation surplus, that is, the increase in net worth as shown on the balance sheet which occurs when a corporation writes up assets to reflect what is believed to be their real, but as yet unrealized, appreciation in value over their book value, or historical cost less depreciation. ${ }^{1.50}$

The porosity of ordinary corporation law's barriers against outflows of a corporation's minimum cushion of capital for creditors and the use of irrelevant legal-accounting methods of computing the cushion have a number of consequences. First, except insofar as fair market value accounting impinges on the traditional accounting tests, the statutory restrictions probably lead to less litigation than would a less mechanical test such as maintenance of a net worth reasonable in light of the nature of the particular business and its liabilities. Dividend-restricting statutes are generally easier than fraudulent conveyance law for courts and shareholders to apply.

However, other consequences of these statutes are less laudable and derived from the slight protection provided by the restraints. Most lenders to corporations, if at all sophisticated, do not rely on the statutory capital cushions. If it is worth their while to obtain protection beyond that afforded by the overarching insolvency test, they will bargain to obtain security interests or protective provisions in their loan agreements containing more effective restrictions on dividends and other distributions. Another consequence is that it is possible for tort creditors of a corporation to be adversely affected by the weak dividend restraints of ordinary business corporation law. At the time a tort claim arises, the corporation's net worth, and even the assets available for creditors who are not secured, ${ }^{151}$ may have fallen so low

${ }^{148}$ Neither Delaware nor New York has a minimum initial legal or stated capital requirement. See H. Henn, Law of Corporations i40, I43 (i970).

${ }^{149}$ See id. at $2 \mathrm{I}_{4}-\mathrm{I} 5$.

${ }^{150}$ See, e.g., Randall v. Bailey, 23 N.Y.S.2d I73 (Sup. Ct. I940), aff'd without opinion, 262 App. Div. 844, 29 N.Y.S.2d 5I2 (Ist Dept. I94I), aff'd with opinion, 288 N.Y. 280,43 N.E.2d 43 (I 942 ).

A similar situation to that governing dividends exists with respect to distributions in the form of stock repurchases and redemptions.

${ }^{151}$ In recent times, many bankruptcy lawyers have found that in an increasing number of cases in which the bankrupt has assets, almost all of them have been hypothecated to secured creditors. The facilitation of the creation, perfection, and enforcement of security interests in personal property by Article 9 of the Uniform Commercial Code may be partly responsible for this apparent trend. See Countryman, Code Security Interests in Bankruptcy, 75 Comm. L.J. 269 ( 1976$)$. 
because of past dividend payments that the tort creditor's claim will not be satisfied to any significant degree..$^{152}$

Ordinary business corporation law's weak and arbitrary restraints upon shareholder distributions force one to examine the relationship between these restraints and UFCA section 5. Does compliance with these statutory restraints preclude an attack on a distribution to shareholders under the more general rule embodied in UFCA section 5? Furthermore, why should distributions to shareholders be singled out for treatment that is different from that accorded all other kinds of transfers without fair consideration made by a corporate debtor?

I would strongly argue that, when a trustee's suit under Bankruptcy Act section $67 \mathrm{~d}$ is brought, a court can and should hold that the subsection's fraudulent conveyance rules preempt the dividend rules of state corporation laws; and that, when a state has enacted a fraudulent conveyance statute, it ought to be interpreted as providing an additional set of restrictions that dividends and similar distributions must satisfy. There is nothing inherently problematic about barring dividends when a corporation is insolvent either in the equity or the UFCA sense, or when either an impairment of "legal capital" or an unreasonable capital for the particular business would afterwards obtain. Mechanical rules and flexible rules can co-exist, just as law and equity can. As for the statutory protections afforded "innocent" shareholders, they might be conceded to be preemptive, but would usually be of no avail to controlling parties.

However, despite the paucity of case law, ${ }^{153}$ one suspects that as to the first question some courts would wrongly decide that the corporation law's rules concerning dividends preempt the rules of general fraudulent conveyance law. ${ }^{154}$ If this is so, one may hy-

${ }^{152}$ The veil-piercing cases do not appear to be a complete solution to this problem. Not all courts accept unadorned inadequate capitalization as a basis for piercing. Moreover, those that do have focused mainly on the adequacy of the corporation's initial capitalization, rather than on the maintenance of a capital cushion over time, and in any event the shareholders' personal assets may be exempt, inadequate, or pledged to contract creditors.

${ }^{153}$ Approaching the issue, but not resolving it, are: Powers v. Heggie, 268 Mass. 233, I67 N.E. 3 I4 (1929) (trustee in bankruptcy allowed to recover dividends paid when Delaware corporation insolvent; any doubt as to right to do so removed by enactment of UFCA; but Delaware corporation law not in evidence); and Island Paper Co. v. Carthage Timber Corp., I28 Misc. 246, 2 I 8 N.Y.S. 346 (Sup. Ct. 1926) (creditor basing action on theory of violation by dividend of corporate law provision not allowed to shift to fraudulent conveyance theory).

${ }^{154}$ The great Glenn, succumbing to the temptation to rationalize this realistic intuition, for once nods and makes the rather formalistic argument that the theory of fraudulent conveyances will not fit the case of an improper dividend because the stockholder is not within either of the simple categories (donee and purchaser) that are part of the law of fraudulent transfers, but is an investor. Otherwise, he 
pothesize that they continue in existence for reasons other than the protection of creditors, since the corporate law restraints (other than the insolvency tests) are so obviously insignificant. One possible other reason is precisely that statutory restrictions on shareholder distributions supplant more stringent general restrictions on transfers without fair consideration with a set of lax rules that will give management and shareholders greater freedom of action. Less cynically, the statutory restrictions are easily administrable mechanical tests that facilitate corporate planning and decisionmaking, whereas UFCA section 5 provides a vague and uncertain standard; the relevance of the standards to their goal and their efficacy as means have been sacrificed to management's desire for clarity and bright lines. This latter observation also provides whatever answer might be given to the second question. ${ }^{155}$ Management especially wants bright lines concerning the chief recurrent transfers without fair consideration that a corporation makes - dividends and other distributions to shareholders.

The most general, and perhaps the most significant, observation to be made about restrictions on distributions to shareholders is that even if they were modeled after UFCA section 5 , and the concept of reasonable capital was given a strong content, the pro-

simply asserts that "the law of the corporation's being" should govern. 2 G. GLENN, supra note I, \$ 604, at I043-47. Glenn's argument is unconvincing for at least two reasons. First, at least under the UFCA and the Bankruptcy Act, nothing in the language or theory of the statutes requires the fraudulent transferee or obligee to have the status of donee or purchaser: these are commentators' classifications for purposes of convenience. Second, Glenn does not explain why one set of rules should govern unfair dealings by controlling stockholders to the detriment of corporate creditors when the technique of unfairness is a dividend payment, and another set when the technique of unfairness is any other form of transaction, such as a sale of property to the corporation at an excessive price.

Nevertheless, the argument that might persuade some courts as to the exclusivity of corporate law has been expressed:

Where the corporation act, however, contains a provision dealing specifically with the question of insolvency dividends, it would seem that the mere fact more stringent regulations existed in some general act ought not to affect the corporation. The legislature having dealt expressly with the corporate insolvency situation, general principles in other statutes ought not to be given effect.

D. Kehl, Corporate Dividends 36 (r94I). Supporting Kehl's argument are provisions in corporate laws specifically stating the conditions under which stockholders may be liable to corporate creditors for improper dividends received. See W. CARY, supra note I27, at I573-74. Some of these provisions are clearly more lenient than those applicable to the ordinary fraudulent transferee or grantor, e.g., provisions immunizing from any duty to disgorge dividends those stockholders who were ignorant of the impropriety of the dividends, even when the dividends were paid while the corporation was insolvent.

155 Since distributions to shareholders are the chief or only recurrent transfers without fair consideration that an ordinary honest corporation makes, the development of special, fairly definite rules about them would be understandable. 
tection afforded creditors would still be incomplete. When a business corporation's capital sinks below some level that would provide creditors with a legally minimal protection against future adversities, a complete legal response would be to tell the corporate debtor that it must not (a) pay dividends or make other distributions to shareholders, (b) incur additional debts unless they would improve ability to meet existing obligations, or (c) fail to obtain additional equity capital within a reasonable period of time. The absence of any requirement in the nature of (c), in the case of ordinary business corporations, ${ }^{156}$ indicates that the statutory restrictions, as well as fraudulent conveyance law generally, are based on a distinction between misfeasance and nonfeasance. Though shareholders cannot pay themselves before paying the company's creditors, there is no affirmative duty on their part to supply an additional investment to a dying corporation; such a duty would be in fundamental contradiction to the policy of permitting limited liability. Not even the veil-piercing cases decided for plaintiffs on grounds of inadequate initial capital are inclined to carry the affirmative duty of cooperation to the full flowering of a capital maintenance rule.

\section{Conclusions}

This essay began from two starting points: the lack of clarity in the case law about the purposes of fraudulent conveyance law; and the dearth of explicit analysis in the case law and commentary of the relationships among fraudulent conveyance law, equitable subordination doctrine, the doctrine of piercing the corporate veil, and statutory restraints on dividends. The law of fraudulent con-

${ }^{156}$ It is only in the case of certain financial intermediaries, such as banks, savings and loan associations, and insurance companies, that the law strives toward something like an affirmative action program with respect to capital inadequacy. In the regulation of commercial banks, for example, pressuring banks toward capital adequacy, see, e.g., Sheehan, Bank Capital Adequacy - Time To Pause and Reflect, Press Release of Board of Governors of Federal Reserve System (November 6, r973) (hortatory remarks of member of Board), continues to be one of the most important foci of regulatory efforts, even though such efforts have sometimes been analyzed as failures, e.g., Peltzman, Capital Investment in Commercial Banking and Its Relationship to Portfolio Regulation, 78 J. Pol. Econ. I ( 1970), and regulatory agencies like the Federal Reserve Board have devised elaborate mechanical formulae for determining what is adequate capital, id. at 22-24. The explanation of the different legal approaches in this field is that legal protection of the creditors of financial intermediaries is taken much more seriously than that given to ordinary commercial lenders to industrial corporations because the public creditors of the intermediaries - basically, depositors and policyholders - are treated as in need of a special level of protection. This theme, however, must be left for treatment elsewhere. See Clark, The Soundness of Financial Intermediaries, 86 YALE L.J. I ( 1976$)$. 
veyances, together with the law of voidable preferences, implicates a coherent set of conceptually distinct moral principles that should govern the conduct of debtors toward their creditors. These principles of Truth, Respect, and Evenhandedness, which may be grouped under the more general duty of Nonhindrance, are so related to one another in practice and under the standard "rules" of fraudulent conveyance actions that courts understandably have trouble, at times, distinguishing fraudulent conveyances from preferences.

The intellectual progression from fraudulent conveyance law to equitable subordination and to the proposed rule of automatic subordination can be seen as an evolution of modes of implementation of essentially the same ideals. The moral duties of Truth and Respect are specified by fraudulent conveyance law in rather precisely conceived tests, and their violation calls for equally precisely conceived, nonpunitive remedial action. Fraudulent conveyance law was limited in the scope of its protection by the concept of a transfer, and was limited by its restriction to formal creditors rather than extended generally to beneficiaries of a legally imposed moral relationship (such as that imposed on majority shareholders with respect to minority or preferred shareholders). These same moral duties were given expression in a distinct, bankruptcy-related doctrine, that of equitable subordination, precisely in order to overcome the limits of fraudulent conveyance law. Where atomistic, transactionally-oriented proof of violations of the moral duties would be too costly; where precisely conceived, nonpunitive remedies were felt to be infeasible; where violations of the duties occurred without a transfer; and where the duties were owed to obligees who were not legal creditors, new doctrine had to be developed. The courts have found it functional not to characterize these developments in the doctrines of equitable subordination of piercing the corporate veil as an expansion or "weakening" of fraudulent conveyance rules. In my view, this hypothesis constitutes a plausible explanation of the failure of the courts deciding cases invoking these doctrines to draw the rather obvious parallels between what they were doing and the extensive case law concerning fraudulent conveyances.

Furthermore, in some veil-piercing cases and, to a lesser degree, in some equitable subordination cases, courts have experimented with an evolution of the duties themselves, from ideals of Nonhindrance toward ideals of affirmative cooperation with creditors. Statutory restrictions on distributions to shareholders, by contrast, reflect a mechanization and weakening of the ideals.

It is hoped that the courts will continue to develop the doctrines of equitable subordination and veil-piercing, but will do 
so with explicit awareness of the extent to which they are being resorted to as a way of avoiding the requirements of fraudulent conveyance law. As indicated, justifications for the avoidance strategy may be expressed, but these justifications will not extend to relatively simple cases of fraudulent transfers. With respect to those courses of conduct of insiders that can be readily unpacked into untruthful or unfair transactions, the ancient leviathan of commercial law doctrines gives a clearer analysis and a better remedy. 